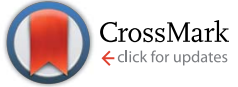

Cite this: RSC Adv., 2017, 7, 8606

Received 15th October 2016 Accepted 23rd November 2016

DOI: $10.1039 / c 6 r a 25295 h$

www.rsc.org/advances

\section{Cadmium and lead remediation using magnetic and non-magnetic sustainable biosorbents derived from Bauhinia purpurea pods $\uparrow$}

\begin{abstract}
Rupa Sharma, ${ }^{a}$ Ankur Sarswat, ${ }^{a}$ Charles U. Pittman Jr. ${ }^{\text {b }}$ and Dinesh Mohan*a
Bauhinia purpurea (Kaniar) pods were dried, powdered, and utilized for cadmium and lead removal. Bauhinia purpurea (Kaniar) pod powders (KPP) were converted into magnetic Bauhinia purpurea (Kaniar) powders (MKPP) by co-precipitation. Iron(II) sulfate and iron(III) sulfate were used as iron precursors. The biosorbents were extensively characterized using zero point charge measurements $\left(\mathrm{pH}_{\mathrm{PZC}}\right)$, ultimate and proximate analyses, Fourier transform infrared (FTIR) and FT-Raman spectroscopy, transmission electron microscopy $(T E M), X$-ray diffraction (XRD), BET surface area $\left(S_{\mathrm{BET}}\right)$ measurements, physical properties measurement system (PPMS), scanning electron microscopy (SEM) and energy dispersive $X$-ray fluorescence (EDXRF) techniques. The $S_{B E T}$ of MKPP $\left(52.0 \mathrm{~m}^{2} \mathrm{~g}^{-1}\right)$ was higher than KPP $\left(1.8 \mathrm{~m}^{2} \mathrm{~g}^{-1}\right)$. Optimum $\mathrm{Cd}^{2+}$ and $\mathrm{Pb}^{2+}$ removal by KPP and MKPP was obtained at $\mathrm{pH} 5.0$ and 4.5 , respectively. Metalligand chelation, ion-exchange and hydrogen bonding were possible mechanisms for $\mathrm{Cd}^{2+}$ and $\mathrm{Pb}^{2+}$ removal. KPP and MKPP showed maximum Langmuir adsorption capacities of 11.1 and $4.8 \mathrm{mg} \mathrm{g}^{-1}$ for $\mathrm{Cd}^{2+}$ and 16.4 and 14.1 for $\mathrm{Pb}^{2+}$, respectively. Lead and cadmium kinetic data were best described using a pseudo-second-order equation. $\mathrm{Cd}^{2+}$ and $\mathrm{Pb}^{2+}$ removal was affected by the presence of $\mathrm{Cu}^{2+}$ during adsorption from a multicomponent aqueous environment. $\mathrm{Cd}^{2+}$ and $\mathrm{Pb}^{2+}$ remediation from actual groundwater was demonstrated. Fixed-bed studies for $\mathrm{Pb}^{2+}$ removal by KPP were also performed with a column capacity of $18.8 \mathrm{mg} \mathrm{g}^{-1}$ (column dia $2.0 \mathrm{~cm}$; column length $40 \mathrm{~cm}$; bed height $6.0 \mathrm{~cm} ; \mathrm{pH}$

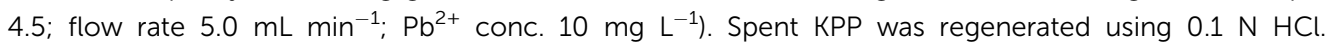
Approximately $85 \%$ of total $\mathrm{Pb}^{2+}$ recovery was achieved using $100 \mathrm{~mL} 0.1 \mathrm{~N} \mathrm{HCl}$.
\end{abstract}

\section{Introduction}

Clean water is a most valuable natural resource. ${ }^{1}$ Water pollution due to heavy metals, dyes, pesticides, pharmaceuticals, arsenic, and fluoride contamination is increasing. ${ }^{2}$ Heavy metals, in particular, are emerging as one of the most common class of water pollutants. ${ }^{3}$ Heavy metals are capable of inducing toxic effects in organisms when present above their permissible concentrations. ${ }^{4}$ Cadmium and lead are highly toxic priority pollutants. ${ }^{5}$ Cadmium contamination in groundwater originates with the manufacturing of alloys, batteries, pigments, plastics, mining and refining processes. ${ }^{6,7}$ Cadmium causes severe damage to kidneys and bones and is associated with itaiitai disease. Its accumulation in the human body leads to erythrocyte destruction, nausea, salivation, diarrhea, muscular cramps, renal degradation, chronic pulmonary problems, and

${ }^{a}$ School of Environmental Sciences, Jawaharlal Nehru University, New Delhi 110067, India. E-mail: dm_1967@hotmail.com; Fax: +91-11-26704616; Tel: +91-11-26704616 ${ }^{b}$ Department of Chemistry, Mississippi State University, Mississippi State, MS 39762, USA

$\dagger$ Electronic supplementary information (ESI) available. See DOI: 10.1039/c6ra25295h skeletal deformity. ${ }^{8}$ Cadmium ions are unlikely to hydrolyze at $\mathrm{pH}<8$ but tend to exist as hydroxo-complexes at $\mathrm{pH}>11 .^{9}$

Mining, smelting, fossil fuels combustion, solid waste incineration, batteries, paints, cables, ceramics and glass manufacturing are common anthropogenic sources of lead contamination in groundwater. ${ }^{\mathbf{1 0 , 1 1}}$ Acute lead poisoning may result to headache, irritability, abdominal pain and various symptoms related to nervous systems. Children are particularly susceptible to lead poisoning due to the high gastro-intestinal barrier and permeable blood-brain barrier. ${ }^{12}$ The World Health Organization $^{\mathbf{1 3}}$ and Bureau of Indian Standards ${ }^{\mathbf{1 4 , 1 5}}$ permissible limits for cadmium and lead in drinking water are 0.003 and $0.01 \mathrm{mg} \mathrm{L}^{-1}$, respectively. Common methods deployed for aqueous $\mathrm{Cd}^{2+}$ and $\mathrm{Pb}^{2+}$ removal include filtration, chemical precipitation, ion-exchange, membrane process, electrodeposition and adsorption. ${ }^{\mathbf{1 6}}$

Adsorption is a simple, effective and economically viable approach, ${ }^{4}$ widely used to remediate heavy metals and other pollutants. ${ }^{17}$ Several adsorbents have been used for $\mathrm{Pb}^{2+}$ and $\mathrm{Cd}^{2+}$ remediation, including clays, minerals (goethite, hydroxyapatite and calcite), and calcareous soils. ${ }^{18}$ Industrial wastes used as $\mathrm{Pb}^{2+}$ and $\mathrm{Cd}^{2+}$ adsorbents include slags, sludges, modified asphaltite ashes, fly ash chitosan, zeolite, humic acid, 
and sesquioxides (iron, aluminium, or manganese oxides). ${ }^{18}$ Some bio-materials, such as bark, dead biomass, modified wool, moss, peat and seaweed, were also applied for aqueous $\mathrm{Cd}^{2+}$ and $\mathrm{Pb}^{2+}$ removal. ${ }^{19}$ Nitrilotriacetic acid anhydride modified ligno-cellulosic material was also used for cadmium and lead removal. ${ }^{20}$ Reviews of contaminant remediation of water by various biosorbents have appeared. ${ }^{\text {21,22 }}$ Activated carbon, the most common adsorbent used to remediate many pollutants ${ }^{23}$ has high production costs. ${ }^{24}$ Therefore, heavy metal removal using a low cost adsorbent is essential to encourage remediation.

Biosorption uses the ability of biological materials to accumulate aqueous heavy metals by metabolically mediated or physico-chemical uptake pathways. ${ }^{25}$ Biosorption can exhibit several advantages including higher sorption capacity, regeneration, and adsorbate recovery. ${ }^{26}$ Olive stones and sugarcane bagasse, ${ }^{27}$ marine microphytes, ${ }^{28}$ Spirulina, ${ }^{29}$ Camellia sinensis ${ }^{30}$ pectin based adsorbent ${ }^{31}$ and fungal and wood adsorbents $^{32}$ were tested for aqueous lead and cadmium removal in single and binary systems. Recently, biosorbents used for heavy metals were reviewed. ${ }^{33}$

Bauhinia purpurea, commonly known as Kaniar or Kachnar, is a small tree. The purple Bauhinia tree (Bauhinia purpurea) is native to lower Himalayan slopes extend up to Assam and throughout the Indian Peninsula. Bauhinia purpurea is also found in Myanmar, Sri Lanka and Southern China. ${ }^{34}$ Bauhinia purpurea leaves, flowers, flower buds, and young pods are edible $^{35}$ and have medicinal value, exhibiting antioxidant, ${ }^{36}$ anti-cancer, ${ }^{37}$ anti-microbial, ${ }^{38}$ and nephroprotective ${ }^{39}$ activities. Bauhinia purpurea can withstand aqueous pollutants. ${ }^{40}$
Also, biomass from Bauhinia leaves was used for dye removal from wastewater. ${ }^{41}$ Thus, we selected, dried, and powdered Bauhinia pods for use as a sustainable biosorbent. Bauhinia purpurea pod powder was also magnetized to prepare magnetic biosorbent. Magnetization allows easy recovery of exhausted biosorbent from aqueous systems using a simple magnet.

\section{Material and methods}

\subsection{Reagents and equipment}

All the chemicals used in the study were either AR or GR grade. Lead nitrate, $\mathrm{Pb}\left(\mathrm{NO}_{3}\right)_{2}(\geq 99 \%)$, cadmium nitrate, $\mathrm{Cd}\left(\mathrm{NO}_{3}\right)_{2}$ ( $\geq 99 \%$ ), iron(II) sulfate, $\mathrm{FeSO}_{4}(99.5 \%$ ), and sodium hydroxide, $\mathrm{NaOH}(98 \%)$ were obtained from Merck, India. Iron(III) sulfate, $\mathrm{Fe}_{2}\left(\mathrm{SO}_{4}\right)_{3}$ (minimum assay $20.50 \%$ ) was purchased from $\mathrm{CDH}$, India.

$\mathrm{Cd}^{2+}$ and $\mathrm{Pb}^{2+}$ stock solutions were prepared in doubly distilled water. Solution pHs were adjusted using $0.1 \mathrm{M}$ nitric acid and sodium hydroxide dilute solutions.

2.1.1. Magnetic and non-magnetic biosorbents development. Fresh Bauhinia purpurea pods were collected, washed, and then sun-dried. Dried pods were ground and sieved into different particle sizes. The 30-50 B.S.S. mesh size range was selected for the sorption experiments. Selected samples were washed several times with distilled water to remove any color. Finally, this powder was dried overnight at $70{ }^{\circ} \mathrm{C}$ and stored in airtight containers for further use (Fig. 1). This biosorbent was designated as KPP.

KPP was magnetized using a chemical precipitation method with modifications discussed earlier. ${ }^{5}$ Briefly, $20 \mathrm{~g}$ of KPP was

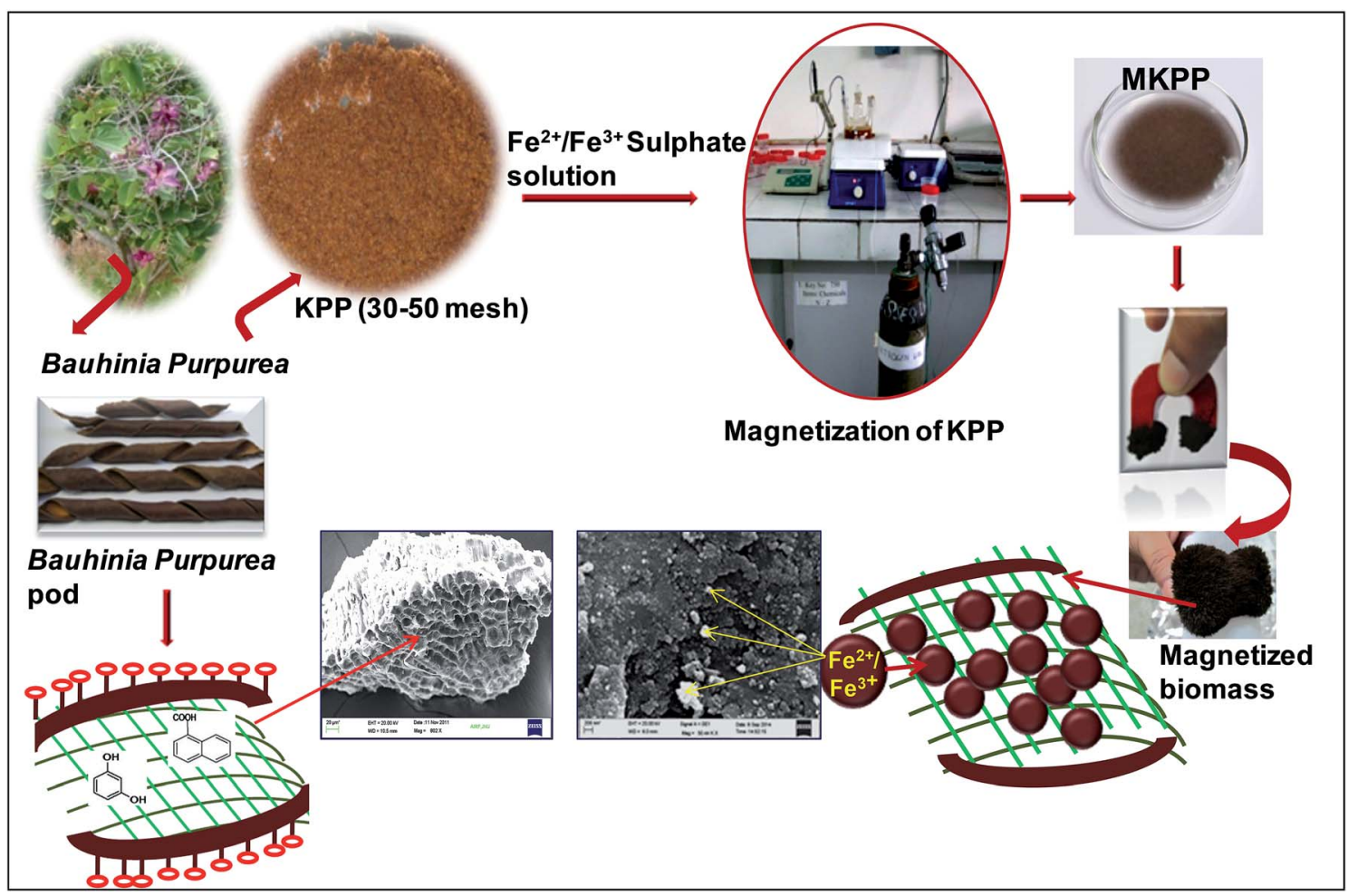

Fig. 1 Schematic diagram for KPP and MKPP development, recovery of spent KPP and MKPP. 
stirred in $200 \mathrm{~mL}$ of double distilled water for $1 \mathrm{~h}$. Ferrous sulfate ( $8 \mathrm{~g}$ in $60 \mathrm{~mL} \mathrm{DW}$ ) and ferric sulfate $(7.4 \mathrm{~g}$ in $20 \mathrm{~mL} \mathrm{DW})$ solutions were mixed together. This ferrous-ferric solution was added to the KPP suspension in a three neck round bottom flask. The suspension was agitated for $1 \mathrm{~h}$ under nitrogen. Then the $\mathrm{pH}$ was raised to $\mathrm{pH}$ 10-11 using a freshly prepared $10 \mathrm{M}$ $\mathrm{NaOH}$. The iron oxide nanoparticles started precipitating on KPP surfaces and inner pores during the $\mathrm{pH}$ rise. The suspension was aged ( $24 \mathrm{~h}$ ), filtered, and washed using distilled water until the $\mathrm{pH}$ was constant at $\sim 7.0$. Finally, the magnetic biosorbent was washed using ethanol and dried overnight at $70{ }^{\circ} \mathrm{C}$. The magnetic biosorbent was designated as MKPP. Fig. 1 shows the schematic diagram for MKPP development.

2.1.2. Characterization. $\mathrm{pH}_{\mathrm{ZPC}}$ is the $\mathrm{pH}$ at which the net charge on the surface resulting from the adsorption on the surface is zero. Surfaces in aqueous solutions are positively charged below their $\mathrm{pH}_{\mathrm{PZC}}$, thereby favor anion adsorption. Surfaces are negatively charged above their $\mathrm{pH}_{\mathrm{PZC}}$ and favor cation adsorption. The zero point charge $\left(\mathrm{pH}_{\mathrm{ZPC}}\right)$ of KPP and MKPP were measured at 1, 2, 4, 6, 8 and $10 \mathrm{~g} \mathrm{~L}^{-1}$. Samples were added in doubly distilled water. Suspensions were brought to a series of $\mathrm{pH}$ values $(\mathrm{pH} \mathrm{2,} \mathrm{3,} \mathrm{4,} \mathrm{5,} \mathrm{6,}$ $7,8,9,10$ ), agitated for $48 \mathrm{~h}$ at room temperature, and after $48 \mathrm{~h}$, the equilibrium $\mathrm{pH}$ values were measured.

An automated surface area and porosity analyzer (model ASAP 2020, Micromeritics) was used for the surface area, total pore volume and pore size analyses of KPP and MKPP. Biomass samples $(0.15 \mathrm{~g})$ were out-gassed at $250{ }^{\circ} \mathrm{C}$ for $12 \mathrm{~h}$ at $<10^{-3}$ Torr, prior to nitrogen adsorption measurements.

Dried samples were degassed prior to the analysis. The Brunauer-Emmett-Teller (BET) surface area was calculated from the BET adsorption plot. The Barrett-Joyner-Halenda $(\mathrm{BJH})^{42}$ adsorption-desorption isotherm was used to determine the pore size distribution. The total micropore volume $\left(W_{0}\right)$ was estimated by the Dubinin-Radushkevich (D-R) method. ${ }^{\mathbf{4 3 , 4 4}}$

The biosorbents moisture, volatile and ash content were analyzed by ASTM method. ${ }^{45}$ The $\mathrm{C}, \mathrm{H}$ and $\mathrm{N}$ were determined using an elemental analyzer (model EURO EA 3000). Ash content was determined by incinerating a $1 \mathrm{~g}$ sample in a muffle furnace (Scientech, India) at $750{ }^{\circ} \mathrm{C}$ for $6 \mathrm{~h}$.

Surface morphology and elemental composition of KPP and MKPP were examined using a scanning electron microscope (model EVO40, Zeiss) at an accelerating voltage of $10000 \mathrm{~V}$, working distance $9900 \mu \mathrm{m}$ and emission current $13300 \mathrm{nA}$ equipped with Bruker EDX system. Samples were gold coated to make a conductive layer and mounted on a copper stub using a double stick carbon tape. ${ }^{5}$

KPP and MKPP elemental analyses were carried out on an energy dispersive X-ray fluorescence spectrometer (model Epsilon 5, PANalytical). KPP and MKPP were mixed with boric acid and pressed using an Insmart System (INSMART XRF 40) at an applied pressure of $5 \mathrm{t}$. The pellet size and exposure area were $34 \mathrm{~mm}$ and $8 \mathrm{~mm}$, respectively.

The FTIR spectra of KPP and MKPP were recorded with a FTIR spectrometer (model 7000, Varian) on KBR pellets (1: 20 ratio) formed at a pressure of $10 \mathrm{t}$.

KPP and MKPP X-ray diffraction (XRD) patterns were obtained on a powder XRD system (model X'Pert PRO, PANalytical) using
$\mathrm{Cu}-\mathrm{K} \alpha$ radiation $(\lambda=1.54 \AA)$ at $45 \mathrm{kV}$ and $40 \mathrm{~mA}$. The samples were scanned from 10 to $90^{\circ}$ with a scan speed of $2^{\circ} \mathrm{min}^{-1}$.

KPP and MKPP morphologies were examined by TEM (model JEM 2100F, JEOL) at $200 \mathrm{kV}$. Samples were ultrasonicated in ethanol for $10 \mathrm{~min}$, vacuum dried, and loaded on an amorphous carbon-coated copper grid.

The MKPP magnetic hysteresis loop was recorded with a Physical Property Measurement System (PPMS) (model T-415, Cryogenic, USA) at $5 \mathrm{~K}$ and $300 \mathrm{~K}$. Powdered samples were filled in gelatinous capsule and sealed with Teflon tape.

The FT-Raman spectra of KPP and MKPP were recorded with FT-Raman spectrometer (model Varian FT-Raman) in the range of $4000-100 \mathrm{~cm}^{-1}$.

\subsection{Sorption procedure}

Sorption equilibrium and dynamic studies were conducted. Sorption parameters are necessary to design a fixed-bed reactor. Biosorption studies for $\mathrm{Pb}^{2+}$ and $\mathrm{Cd}^{2+}$ removal were performed in batch and column modes (Fig. SM1†).

In batch sorption experiments, a fixed adsorbent dose was agitated with $50 \mathrm{~mL}$ of adsorbate at a constant temperature and $\mathrm{pH}$, and for specific time intervals (Fig. SM1†). The metal ion concentration was analyzed on an atomic absorption spectrometer (model Aanalyst 400, Perkin Elmer). Adsorption capacities were calculated using eqn (1).

$$
q_{\mathrm{e}}=\frac{\left(C_{0}-C_{\mathrm{e}}\right)}{W} \times V
$$

here, $q_{\mathrm{e}}$ is the amount $\left(\mathrm{mg} \mathrm{g}^{-1}\right)$ of metal adsorbed, $C_{0}\left(\mathrm{mg} \mathrm{L}^{-1}\right)$ and $C_{\mathrm{e}}\left(\mathrm{mg} \mathrm{L}^{-1}\right)$ are the initial and equilibrium metal concentrations, $W$ is the adsorbent weight $(\mathrm{g})$ and $V(\mathrm{~L})$ is the metal solution volume.

Kinetic and isotherm experiments were conducted to understand the thermodynamic adsorption behavior. A specific amount of adsorbent was added to $50 \mathrm{~mL}$ of adsorbate solution in the concentration range of $2-100 \mathrm{mg} \mathrm{L}^{-1}$ at temperatures 25 , 35 and $45{ }^{\circ} \mathrm{C}$. Sorption equilibrium and dynamics data were fitted to various isotherm models and rate equations.

Column experiments provide necessary parameters for scaling up fixed-bed reactors. Flow rate, bed-height, column width, and breakthrough time were obtained through column adsorption (Fig. SM1 $\dagger$ ).

2.2.1. Sorption equilibrium models. Freundlich, ${ }^{46}$ Langmuir, ${ }^{47}$ Temkin, ${ }^{48}$ Sips or Langmuir-Freundlich, ${ }^{\mathbf{4 9}}$ RedlichPeterson, ${ }^{50}$ Radke and Prausnitz, ${ }^{51}$ Toth, ${ }^{52}$ and Koble-Corrigan, ${ }^{53}$ models were used to fit the equilibrium data obtained for lead and cadmium adsorption on KPP and MKPP. A detailed discussion of the isotherm models are given in Table SM1. $\dagger$

\subsubsection{Kinetic models}

(a) Pseudo-first-order model. The pseudo-first-order model is given in eqn (2)..$^{5,54,55}$

$$
q_{t}=q_{\mathrm{e}}\left(1-\mathrm{e}^{-k_{1} t}\right)
$$

here, $k_{1}$ is first-order rate constant $\left(\min ^{-1}\right), q_{\mathrm{e}}$ is adsorbate adsorbed per gram of adsorbent, and $q_{t}$ is adsorbate adsorbed at time ' $t$ '. 
(b) Pseudo-second-order model. Pseudo-second-order adsorption (eqn (3)) is greatly influenced by the number of active sites on adsorbent surface..$^{\mathbf{8 5 5}}$

$$
\frac{t}{q_{t}}=\frac{1}{k_{2} q_{\mathrm{e}}^{2}}+\frac{t}{q_{\mathrm{e}}}
$$

here, $k_{2}\left(\mathrm{~g} \mathrm{mg}^{-1} \mathrm{~min}^{-1}\right)$ is the pseudo-second order rate constant, $q_{\mathrm{e}}\left(\mathrm{mg} \mathrm{g}^{-1}\right)$ is the amount of adsorbate adsorbed at equilibrium, and $q_{t}\left(\mathrm{mg} \mathrm{g}^{-1}\right)$ is the amount of adsorbate adsorbed at any time $t$.

\subsection{Thermodynamic studies}

The thermodynamic studies were performed at various $\mathrm{Pb}^{2+}$ and $\mathrm{Cd}^{2+}$ initial concentrations $\left(10-100 \mathrm{mg} \mathrm{L}^{-1}\right)$ at 25,35 , and $45^{\circ} \mathrm{C}$. The thermodynamic parameters, $\Delta S^{\circ}$ (entropy), $\Delta G^{\circ}$ (Gibbs free energy) and $\Delta H^{\circ}$ (enthalpy), were evaluated using the eqn $(4)-(6) .{ }^{56}$

$$
\begin{gathered}
\Delta G^{\circ}=-R T \ln b \\
\Delta H^{\circ}=R\left(\frac{T_{1} T_{2}}{T_{1}-T_{2}}\right) \ln \frac{b_{1}}{b_{2}} \\
\Delta S^{\circ}=\frac{\Delta H^{\circ}-\Delta G^{\circ}}{T}
\end{gathered}
$$

where $b, b_{1}, b_{2}$ are the constants the Langmuir constants at 25, 35 , and $45{ }^{\circ} \mathrm{C}$ while $R$ and $T$ are the gas constant $\left(8.314 \mathrm{~J} \mathrm{~mol}^{-1}\right.$ $\mathrm{K}^{-1}$ ) and the absolute temperature, respectively.

\subsection{Fixed-bed studies of $\mathbf{P b}^{2+}$ removal and desorption}

Adsorption isotherms are conventionally used for preliminary investigations and to know the operational parameters. However, it is essential to obtain a factual design model for practical applicability of biosorbents in column operations. A column $(40.0 \times 2.0 \mathrm{~cm})$ was filled with KPP $(30-50$ B.S.S. mesh) with glass wool support (Fig. SM1 $\dagger$ ). The biosorbent ( 5 g) was slurried with hot water and fed slowly into the column to avoid air entrapment. The column was then loaded with the adsorbate $\left(\mathrm{Pb}^{2+}\right)$, which percolated downward with a flow rate of $5.0 \mathrm{~mL}$ $\min ^{-1}$. The bed height was $6.0 \mathrm{~cm}$. The influent lead concentration and the solution $\mathrm{pH}$ were $10 \mathrm{mg} \mathrm{L}^{-1}$ and 4.5 , respectively. Effluent samples were collected from the outlet of the column at different time intervals until the effluent lead concentration became nearly equal to the influent lead concentration. The adsorbent was regenerated using $0.1 \mathrm{~N} \mathrm{HCl}$ by elution through the column as during the adsorption step.

\subsection{Application of KPP and MKPP biosorbents in an actual groundwater sample}

Actual wastewater is often a complex system of multiple ions. During $\mathrm{Pb}^{2+}$ and $\mathrm{Cd}^{2+}$ adsorption, these other ions can compete for adsorption sites. The ions may change the adsorption efficiency of an adsorbent. The effect of interfering ions on $\mathrm{Pb}^{2+}$ and $\mathrm{Cd}^{2+}$ adsorption was tested on a groundwater sample collected from Khekra, Baghpat district Uttar Pradesh, India at latitude $28^{\circ} 52^{\prime} 00^{\prime \prime} \mathrm{N}$, and longitude $77^{\circ} 17^{\prime} 00^{\prime \prime}$. This groundwater sample was spiked with a concentration of $50 \mathrm{mg}$ $\mathrm{L}^{-1}$ of both $\mathrm{Pb}^{2+}$ and $\mathrm{Cd}^{2+}$ solution. Adsorption studies were conducted at an adsorbent dose of $1 \mathrm{~g} \mathrm{~L}^{-1}$ (KPP) and $2 \mathrm{~g} \mathrm{~L}^{-1}$ (MKPP) at $25{ }^{\circ} \mathrm{C}$ for $24 \mathrm{~h}$. After $24 \mathrm{~h}$, the samples were filtered and analyzed for the concentrations of $\mathrm{Na}^{+}, \mathrm{Ca}^{2+}$, and $\mathrm{Mg}^{2+}$. The sample's conductivity was also measured after adsorption.

\subsection{Application of magnetic and non-magnetic biosorbents in multicomponent adsorption of $\mathrm{Pb}^{2+}$ and $\mathrm{Cd}^{2+}$}

The adsorption capacity of MKPP and KPP for $\mathrm{Pb}^{2+}$ and $\mathrm{Cd}^{2+}$ from a multicomponent system containing more than one metal ion was examined in the batch mode. Adsorption experiments were conducted on equimolar ratios $(1: 1: 1)$ of $\mathrm{Pb}^{2+}$, $\mathrm{Cd}^{2+}$ and $\mathrm{Cu}^{2+}$. The concentration range used was $2-100 \mathrm{mg} \mathrm{L}^{-1}$. Test solutions were made at $\mathrm{pH} 4.5$ for $\mathrm{Pb}^{2+}$ adsorption. Studies were conducted at $25^{\circ} \mathrm{C}$ by adding $1 \mathrm{~g} \mathrm{~L}^{-1}$ of adsorbent to $50 \mathrm{~mL}$ of each test solution. All samples were agitated for $24 \mathrm{~h}$. After that, all the equilibrium $\mathrm{pH}$ values were measured. Then the $\mathrm{Pb}^{2+}$ and $\mathrm{Cd}^{2+}$ concentrations were analyzed.

\section{Results and discussion}

\subsection{Characterization of KPP and MKPP}

The BET surface areas of KPP and MKPP were $1.8 \mathrm{~m}^{2} \mathrm{~g}^{-1}$ and 52 $\mathrm{m}^{2} \mathrm{~g}^{-1}$, respectively, versus cupuassu shell $\left(1.2 \mathrm{~m}^{2} \mathrm{~g}^{-1}\right)$ [Fig. SM2(A and B) $\dagger$ ]. ${ }^{57}$ The surface area of agricultural residues is usually low. ${ }^{57}$ There was a sharp increase in surface area upon magnetization due to the presence of small bound iron oxide particles in MKPP [Fig. SM2(B)†]. The average pore diameter (BJH) of KPP and MKPP were $22.6 \mathrm{~nm}$ and $15.3 \mathrm{~nm}$, respectively [Fig. SM3(A and B) †]. The average pore diameters of KPP and MKPP are mainly of the mesoporous type. The average pore volumes of KPP and MKPP were $0.01 \mathrm{~cm}^{3} \mathrm{~g}^{-1}$ and $0.20 \mathrm{~cm}^{3} \mathrm{~g}^{-1}$.

KPP and MKPP showed acidic $\mathrm{pH}_{\mathrm{PZC}}$ values of 4.0 and 5.0, respectively [Fig. 2(a and b)]. Thus, KPP and MKPP have acidic surfaces with many oxygenated functional groups, including carboxylic acids, phenols, catechols, acidic alcohols, and enols on the biomass and surface $\mathrm{Fe}-\mathrm{OH}$ groups on the iron oxide particles. The oxygen content was 40 and $32 \%$ for KPP and MKPP, respectively. Some of these oxygenated functional groups may form chelates with $\mathrm{Pb}^{2+}$ and $\mathrm{Cd}^{2+}$.

Elemental analyses of KPP and MKPP showed the presence of traces of $\mathrm{S}, \mathrm{P}, \mathrm{Cl}, \mathrm{K}, \mathrm{Ca}, \mathrm{Cu}$, and $\mathrm{Zn}$ (Table 1). A small wt\% of iron (4\%) was estimated in MKPP while none appeared in KPP. This demonstrated successful loading of iron oxide on KPP (Table 1).

XRD was employed to identify crystalline phases in KPP and MKPP. The degree of crystallinity for biomass has been reported in the range of $13-17 \%$ and $20-23 \%$ is due to cellulosic polymorphs. ${ }^{5,59}$ The $20-23 \%$ degree of crystallinity occurs as a broad diffusion peak attributed to two cellulosic polymorphs, waxes and the complex nature of bonding between these structures. $^{58}$ X-ray diffraction of non-magnetic Kaniar pod powder (KPP) shows a broad peak $(2 \theta=22)$ due to the cellulose(II) crystalline form [Fig. 3(a)]. The width of this peak may be ascribed to the presence of other organic matter such as lignin 

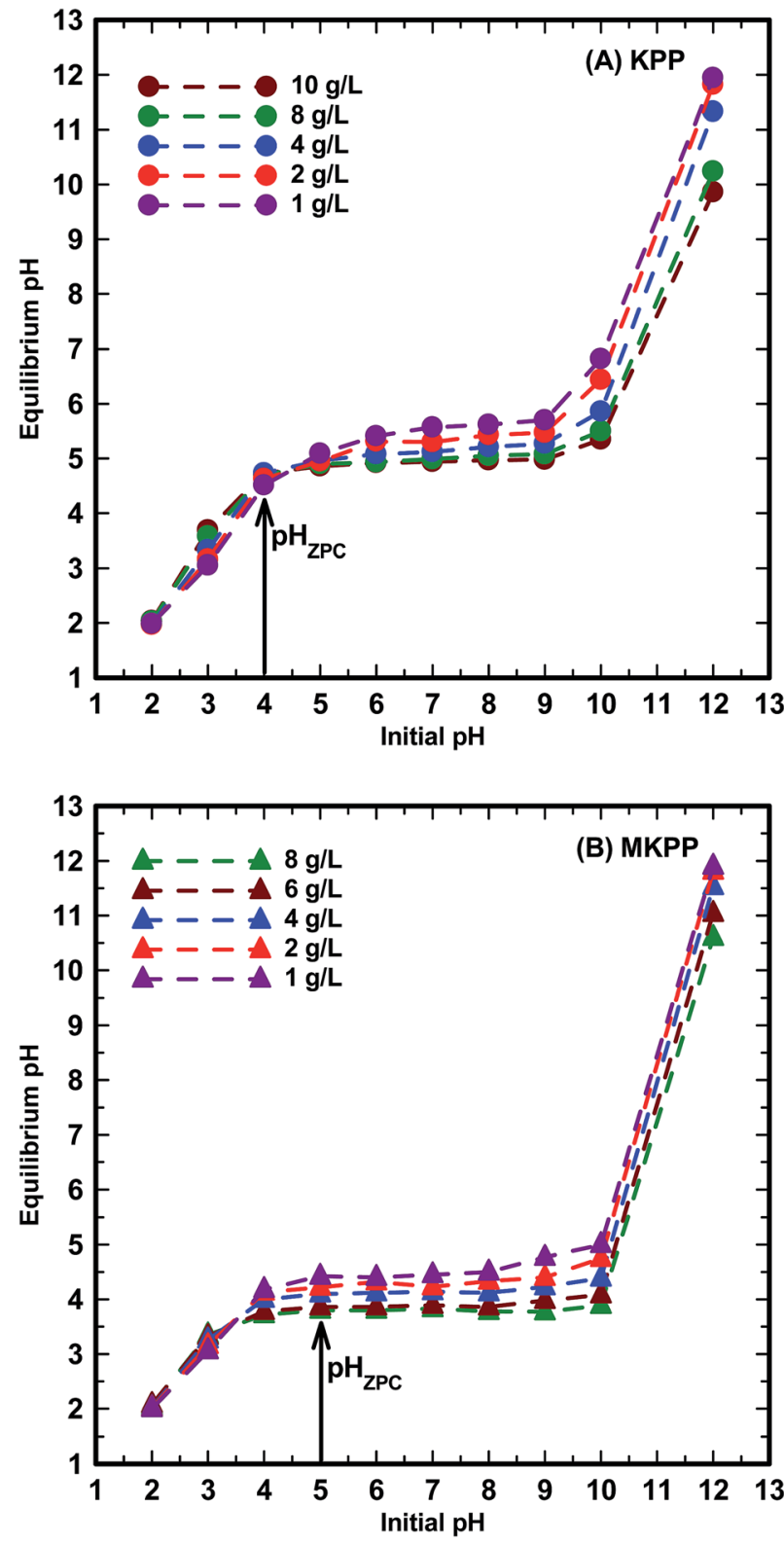

Fig. 2 Effect of adsorbent amount on the equilibrium $\mathrm{pH}$ of the water with no $\mathrm{Pb}^{2+}$ and $\mathrm{Cd}^{2+}$ concentration onto (A) KPP and (B) MKPP.

and hemicellulosic. ${ }^{58,60}$ The other peaks at $2 \theta=43.5^{\circ}, 51.06^{\circ}$, $72.63^{\circ}$ observed for this powder are assigned to cristobolite, quartz, and cristobolite quartz, respectively. The silica may be present both as cristobolite, and quartz. Other than silica, an intense calcite peak is also present at $2 \theta=72.63^{\circ} \cdot{ }^{60,61}$ Most silicate mineral components of biomass contribute to the plant's rigidness and posture. Mineral introduction into the plants can take place through both natural and anthropogenic routes. Majority of transport in plants is routed from soil, where minerals are in abundance. ${ }^{58}$ The iron oxide phase in MKPP, identified as magnetite $\left(\mathrm{Fe}_{3} \mathrm{O}_{4}\right)$, has some intense iron oxide XRD peaks [Fig. 3(b)]. These characteristic magnetite peaks $(2 \theta$ $=30.1,35.4,43.0,57.0$, and 62.5) and their indices [(220), (311), (400), (511), (440)] are observed in Fig. 3(b).
Table 1 Properties of non-magnetic Kaniar pod powders (KPP) and magnetic Kaniar pod powders (MKPP)

\begin{tabular}{|c|c|c|}
\hline Properties & KPP & MKPP \\
\hline \multicolumn{3}{|l|}{ Proximate analyses } \\
\hline Moisture (wt\%) & 4.7 & 3.8 \\
\hline Ash (wt\%) & 0.06 & 12.5 \\
\hline Volatile (wt\%) & 49.6 & 44.6 \\
\hline Fixed carbon (wt\%) & 45.7 & 39.1 \\
\hline Water holding capacity (\%) & 44.5 & 52.9 \\
\hline \multicolumn{3}{|l|}{ Ultimate analyses } \\
\hline $\mathrm{C}(\mathrm{wt} \%)$ & 47.0 & 42.0 \\
\hline $\mathrm{H}(\mathrm{wt} \%)$ & 6.3 & 5.5 \\
\hline $\mathrm{N}(\mathrm{wt} \%)$ & 6.1 & 7.8 \\
\hline $\mathrm{O}(\mathrm{wt} \%)$ & 40.6 & 32.3 \\
\hline \multicolumn{3}{|l|}{ Elemental analyses } \\
\hline $\mathrm{S}(\mathrm{ppm})$ & 181.4 & 1638 \\
\hline $\mathrm{P}(\mathrm{ppm})$ & 108.1 & 838 \\
\hline $\mathrm{Cl}(\mathrm{ppm})$ & 26.2 & 25.8 \\
\hline $\mathrm{K}(\mathrm{ppm})$ & 37.7 & 5.9 \\
\hline $\mathrm{Ca}(\mathrm{ppm})$ & 1961 & 1026 \\
\hline $\mathrm{Cu}(\mathrm{ppm})$ & 10.6 & 18.4 \\
\hline Zn (ppm) & 6.6 & 16.9 \\
\hline Fe $(\%)$ & - & 4.02 \\
\hline \multicolumn{3}{|l|}{ Surface area characterization } \\
\hline$S_{\mathrm{BET}}\left(\mathrm{m}^{2} \mathrm{~g}^{-1}\right)$ & 1.8 & 52.0 \\
\hline$V_{\mathrm{T}}\left(\mathrm{cm}^{3} \mathrm{~g}^{-1}\right)$ & 0.01 & 0.2 \\
\hline Bulk density $\left(\mathrm{cm}^{3} \mathrm{~g}^{-1}\right)$ & 0.18 & - \\
\hline $\mathrm{pH}_{\mathrm{PZC}}$ & $\sim 4.0$ & $\sim 5.0$ \\
\hline
\end{tabular}

The other diffraction peak in KPP and MKPP near $30^{\circ}$ is due to the presence of sulfate minerals. Another less intense peak, observed at $53.8^{\circ}$, corresponds to hematite. ${ }^{62}$ Hematite is also deposited in addition to magnetite in the magnetic biomass during the magnetization process. Use of iron sulfate during MKPP synthesis accounts for some hematite formation. ${ }^{58}$ XRD confirms iron oxide deposition occurs on the KPP surfaces. ${ }^{63}$

SEM micrographs of KPP and MKPP, before and after $\mathrm{Pb}^{2+}$ and $\mathrm{Cd}^{2+}$ adsorption, are shown in Fig. 4(A and B) and 5(A and B). KPP surfaces are rough, shiny and heterogeneous, with a rugged morphology [Fig. 4(A and B)]. This suggests potential for their $\mathrm{Pb}^{2+}$ and $\mathrm{Cd}^{2+}$ sorption within pores. ${ }^{64}$ The morphology of MKPP was entirely different from KPP [Fig. 5(A and B)]. MKPP appeared brighter than KPP. ${ }^{65}$ The cavernous openings seen for KPP in Fig. 4(B) appear to be smoothed over in MKPP (Fig. 5(B) and (C)). Nevertheless MKPP has the greater BET surface area.

Fig. $[4(\mathrm{C}-\mathrm{F})$ and $5(\mathrm{C}-\mathrm{F})]$ shows the spatial distribution of elements on KPP and MKPP, respectively, using SEM-EDX mapping. As seen in Fig. [4(D and F) and 5(D and F)], $\mathrm{Cd}^{2+}$ and $\mathrm{Pb}^{2+}$ are uniformly distributed over KPP and MKPP surfaces after their adsorption. However, surface $\mathrm{Cd}^{2+}$ and $\mathrm{Pb}^{2+}$ concentrations are greater on KPP than MKPP. This is evident by more dense yellow spots of $\mathrm{Cd}^{2+}$ and $\mathrm{Pb}^{2+}$ present on KPP than MKPP surfaces [Fig. 4(D and F) and 5(D and F)]. However, MKPP had more than 28 times as much BET measured surface area where adsorbed metal ions could be spread out on. 

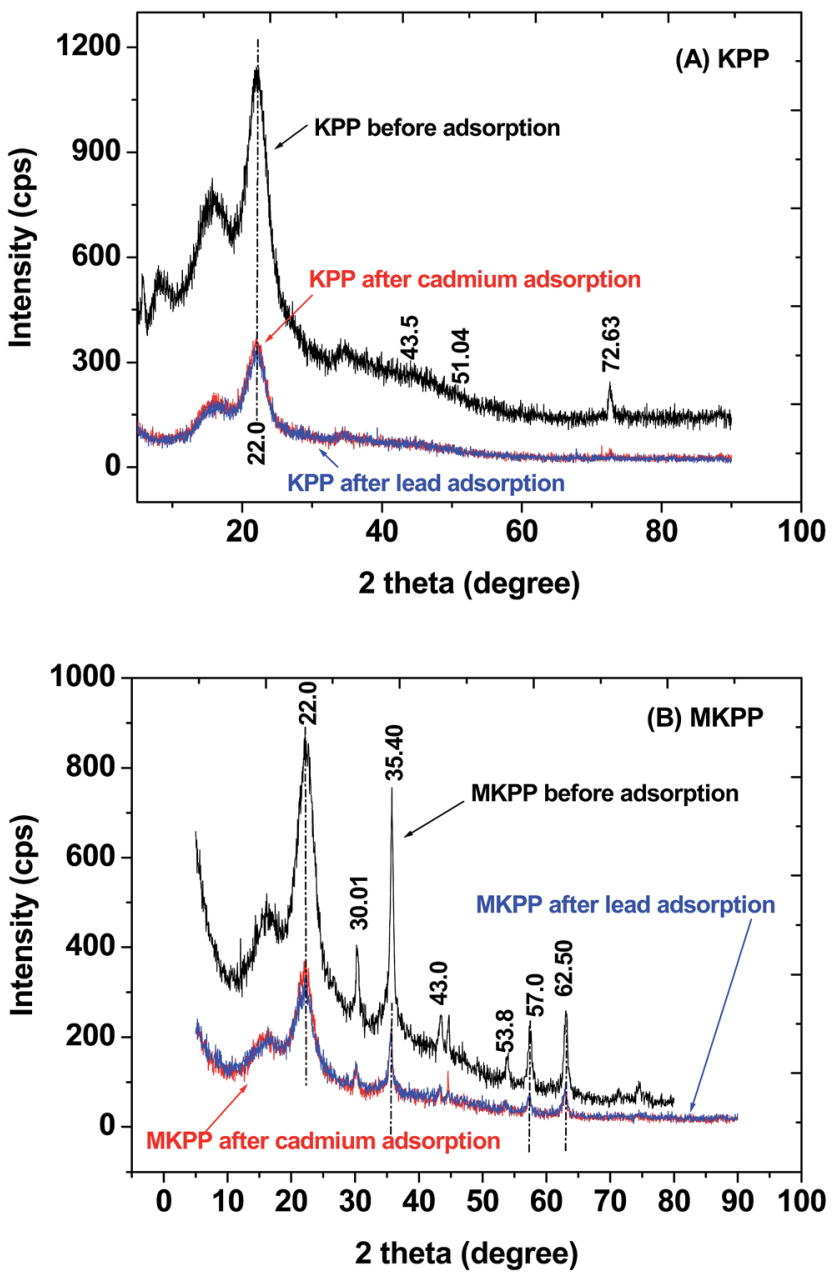

Fig. 3 XRD spectra of (A) Kaniar pod powder (KPP) and (B) magnetized Kaniar pods powder (MKPP) before and after $\mathrm{Pb}^{2+}$ and $\mathrm{Cd}^{2+}$ adsorption.

TEM micrographs of KPP are shown in Fig. 6(A). TEM and electron diffraction (ED) micrographs of MKPP are shown in Fig. 6(B-D). Fig. 6(C) inset shows the diffraction pattern obtained for MKPP. The lattice fringes of magnetite are also obtained [Fig. 6(D)]. The aggregation of MKPP primary particles may be due to the agglomerating tendency of the KPP portions of the exposed surfaces. ${ }^{66}$ The high-resolution TEM (HRTEM) image of the selected area shows a highly crystalline character with a well ordered lattice. This lattice structure observed by HRTEM is consistent with the iron oxide peak position in the XRD pattern [Fig. 6(D)]. The corresponding selected area electron diffraction (SAED) pattern [inset of Fig. 6(C)] displays aggregated semispherical particles indicating this hybrid biocomposite's polycrystalline nature. ${ }^{67}$

Fig. 7(A and B) shows FTIR spectra of KPP and MKPP before and after both $\mathrm{Pb}^{2+}$ and $\mathrm{Cd}^{2+}$ adsorption. KPP exhibited an intense broad band from about $3500-2700 \mathrm{~cm}^{-1}$ maximizing at $3421 \mathrm{~cm}^{-1}$. This is due to the combination of isolated and hydrogen-bonded aliphatic, phenolic, and carboxylic acid $\mathrm{O}-\mathrm{H}$ stretching bands. ${ }^{68,69}$ Both $\mathrm{sp}^{2} \mathrm{C}-\mathrm{H}$ and $\mathrm{sp}^{3} \mathrm{C}-\mathrm{H}$ stretching are buried in this envelop in the $3100-2800 \mathrm{~cm}^{-1}$ region. ${ }^{70}$ Other bands were observed at 2247, 1751, 1517, 1271, 1145, 954 and $669 \mathrm{~cm}^{-1}$. These correspond, respectively, to $\mathrm{CO}_{2}$ at $2247 \mathrm{~cm}^{-1}$, carbonyl stretching at $1751 \mathrm{~cm}^{-1},{ }^{65} \mathrm{sp}^{2} \mathrm{C}-\mathrm{O}$ stretching of carboxylic acids and esters $\left(1271 \mathrm{~cm}^{-1}\right)$, ether and free alcohol $\mathrm{sp}^{3} \mathrm{C}-\mathrm{O}$ stretching (1000-1280 $\left.\mathrm{cm}^{-1}\right),{ }^{58}$ and out-of-plane $\mathrm{H}$ deformations on substituted phenyl rings $\left(669 \mathrm{~cm}^{-1}\right){ }^{71}$

Major FTIR peak shifts and disappearances were observed in the post-adsorption biosorbent samples. Peaks at 3568, 3500$2800,2247,1517,1271,1145$, and $954 \mathrm{~cm}^{-1}$ disappeared and the quality of the spectra became very poor. New peaks at 2366, 1631, and $1558 \mathrm{~cm}^{-1}$ appeared after metal adsorption on KPP [Fig. 7(A and $\mathrm{B})]$. The decrease in free hydroxyl group intensity corresponds to $\mathrm{Cd}^{2+}$ coordination to carboxylic acid, phenolic and other possible sites. Smaller changes are observed in Fig. 7 after $\mathrm{Pb}^{2+}$ biosorption. The FTIR spectrum is consistent with $\mathrm{Pb}^{2+}$ coordination or chelation to carbonyl and other hydroxyl sites on the surface. The FTIR spectra of MKPP (pristine and loaded) exhibit the same before-to-after type changes upon sorption of $\mathrm{Pb}^{2+}$ and $\mathrm{Cd}^{2+}$ [Fig. 7(B)]. Iron oxide deposition alone on lowers the quality of the spectrum of the biostructure portion of the adsorbent. Coordination of $\mathrm{Pb}^{2+}$ and $\mathrm{Cd}^{2+}$ with carboxylic acids lowers the carbonyl stretching frequency and broadens this 1800-1700 $\mathrm{cm}^{-1}$ region. The fact these bands largely disappear in both Fig. 7(A and B) may correspond to this coordination.

The Raman spectra of pristine and loaded KPP and MKPP are shown in Fig. SM4(A and B). $\dagger$ KPP's Raman bands at 3174, 3005 , and $2677 \mathrm{~cm}^{-1}$ are $\mathrm{C}-\mathrm{H}$ stretching vibrations. ${ }^{72} \mathrm{sp}^{2} \mathrm{C}-\mathrm{H}$ (aromatic and olefin) stretching were observed at 3025 and 3006 $\mathrm{cm}^{-1} \cdot{ }^{73}$ Peaks at 3174 and $3005 \mathrm{~cm}^{-1}$ in both KPP and MKPP were observed. The deformation vibration (scissoring mode) of the $\mathrm{CH}_{2}$ group appears in the $1450-1480 \mathrm{~cm}^{-1}$ region. ${ }^{74}$ The band at $1465 \mathrm{~cm}^{-1}$ in KPP and MKPP may be due to the $\mathrm{CH}_{2}$ group. The bands observed from 950 to $1150 \mathrm{~cm}^{-1}$ are assigned to stretches of skeletal rings of cellulosic, hemicellulosic, lignin and glycosidic $\mathrm{C}-\mathrm{O}$ and alcoholic $\mathrm{C}-\mathrm{O}$ bonds. ${ }^{58,74}$

After adsorption of $\mathrm{Pb}^{2+}$ and $\mathrm{Cd}^{2+}$ by KPP and MKPP, the FTRaman spectra looked very similar to the spectra before adsorption. These spectra are not useful in trying to understand any specifics about the adsorption process at the surface.

The saturation magnetization $\left(M_{\mathrm{s}}\right)$ of the composite was investigated at $5 \mathrm{~K}$ and $300 \mathrm{~K}$ using a using a physical property measurement system (PPMS) with an applied field range of $-8000 \mathrm{O}_{\mathrm{e}} \leq H \leq 8000 \mathrm{O}_{\mathrm{e}}$ for quantitative confirmation of the adsorbent's magnetization. The magnetic hysteresis loop of MKPP is shown in Fig. 8. The MKPP sample is ferromagnetic. The $M_{\mathrm{S}}$ values were $5.98 \mathrm{emu} \mathrm{g}^{-1}$ and $8.38 \mathrm{emu} \mathrm{g}^{-1}$ at $300 \mathrm{~K}$ and $5 \mathrm{~K}$, respectively. MKPP responded well when removed by a laboratory magnet from batch slurry adsorption experiments. The $M_{\mathrm{s}}$ values confirm convenient magnetic separations of exhausted adsorbent are possible from many media.

\subsection{Effect of initial $\mathbf{p H}$}

The effect of $\mathrm{pH}$ on $\mathrm{Pb}^{2+}$ and $\mathrm{Cd}^{2+}$ adsorption onto KPP and MKPP is shown in Fig. 9(A and B). Adsorption of metals is a $\mathrm{pH}-$ dependent process as the surface charge and the metal speciation are both affected by the solution $\mathrm{pH}$. The solution $\mathrm{pH}$ affects 

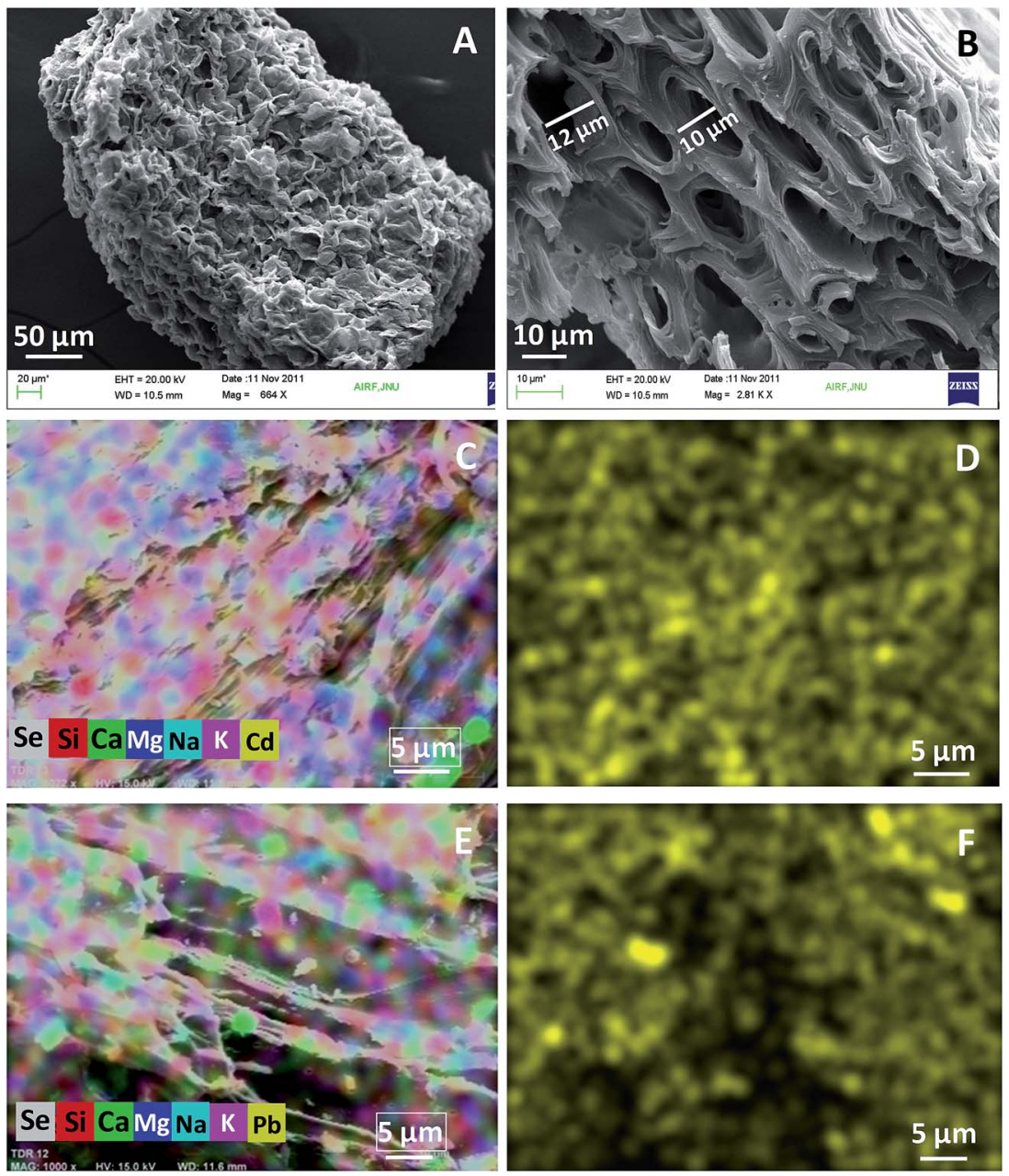

Fig. 4 SEM micrographs of Kaniar pod powder (KPP) at (A) $664 \times(B) 2.81 \mathrm{k} \times$ and SEM-mapping images of (C) multielements with Cd ${ }^{2+}$ and (D) $\mathrm{Cd}^{2+}(\mathrm{E})$ multielements with $\mathrm{Pb}^{2+}$ and $(\mathrm{F}) \mathrm{Pb}^{2+}$ distribution.

the degree of dissociation of the carboxyl and hydroxyl functional groups of the adsorbent and the solubility of metal ions. ${ }^{75,76}$ Sorption of $\mathrm{Pb}^{2+}$ and $\mathrm{Cd}^{2+}$ on MKPP and KPP were restricted to the $\mathrm{pH}$ range from 2.0 to 6.0 to avoid metal ion precipitation. Lead and cadmium exist as $\mathrm{Pb}^{2+}$ and $\mathrm{Cd}^{2+}$ ions at $\mathrm{pH} 4.5$ and 5.0, respectively. ${ }^{76} \mathrm{~Pb}^{2+}$ and $\mathrm{Cd}^{2+}$ sorption increased significantly as $\mathrm{pH}$ increased from 2 to 4 and then modestly increased from 4.0 to 6.0. The $\mathrm{Pb}^{2+}$ and $\mathrm{Cd}^{2+}$ ions may undergo solvation, hydrolysis and polymerization to insoluble hydroxide/oxide species at $\mathrm{pH}$ 7.0, where precipitation can ensue (eqn (7)-(9)). ${ }^{5}$

$$
\begin{gathered}
\mathrm{M}^{2+}+n \mathrm{H}_{2} \mathrm{O} \rightleftarrows \mathrm{M}\left(\mathrm{H}_{2} \mathrm{O}\right)_{n}{ }^{2+} \\
\mathrm{M}\left(\mathrm{H}_{2} \mathrm{O}\right)_{n}{ }^{2+} \rightleftarrows \mathrm{M}\left(\mathrm{H}_{2} \mathrm{O}\right)_{n-1}\left(\mathrm{OH}^{+}\right)+\mathrm{H}^{+} \\
n \mathrm{M}^{2+}+m \mathrm{H}_{2} \mathrm{O} \rightleftarrows \mathrm{M}_{n}(\mathrm{OH})_{m}{ }^{(2 n-m)}+m \mathrm{H}^{+}
\end{gathered}
$$

The $\mathrm{pH}$ dependent adsorption of $\mathrm{Pb}^{2+}$ and $\mathrm{Cd}^{2+}$ between 2 to 6 occurs due to progressive deprotonation of KPP and MKPP surfaces. At $\mathrm{pH}$ 2.0, the biomass surface is positively charged and repels $\mathrm{Pb}^{2+}$ and $\mathrm{Cd}^{2+}$, resulting in low metal uptake. ${ }^{77}$ As
$\mathrm{pH}$ raises, carboxylic acids, enols, and acidic alcohols on the adsorbent loose protons, and the surface becomes more negatively charged. This attracts and binds $\mathrm{Pb}^{2+}$ and $\mathrm{Cd}^{2+}$. As negative charge density increases at the surface, more $\mathrm{Pb}^{2+}$ and $\mathrm{Cd}^{2+}$ are adsorbed. Carboxylic acids are most acidic and lose protons first, followed by acidic alcohol sites. At higher $\mathrm{pH}$, phenols are increasing converted to phenoxide sites, but this effect will occur most strongly from $\mathrm{pH}$ 7.5-10.0, beyond the $\mathrm{pH}$ range studied. In MKPP, magnetite surfaces contain $\mathrm{Fe}-\mathrm{OH}$ groups. These groups also deprotonate progressively as $\mathrm{pH}$ rises or increasingly protonate at low $\mathrm{pH}$. Thus, varying solution $\mathrm{pH}$ biases both surface charging and attraction or repulsion of $\mathrm{Pb}^{2+}$ and $\mathrm{Cd}^{2+}$ of the magnetic surface similar to the biological cell walls of KPP. The individual functional group protonation/deprotonation equilibria are all occurring as a function of solution $\mathrm{pH}$ and within the surface-wide context of the $\mathrm{PH}_{\mathrm{ZPC}}$, which have values of 5.0 for KPP and 4.0 for MKPP [Fig. 2(A and B)].

Maximum $\mathrm{Pb}^{2+}$ and $\mathrm{Cd}^{2+}$ removal occurred at $\mathrm{pH} 4.5$ and 5.0 for KPP and MKPP, respectively [Fig. 9(A and B)]. At a metal concentration of $10 \mathrm{mg} \mathrm{L}^{-1}$ and a $2 \mathrm{~g} \mathrm{~L}^{-1}$ adsorbent dose, $\mathrm{Pb}^{2+}$ removal increased from 24 to $98 \%$ for KPP and 13 to $83 \%$ for 

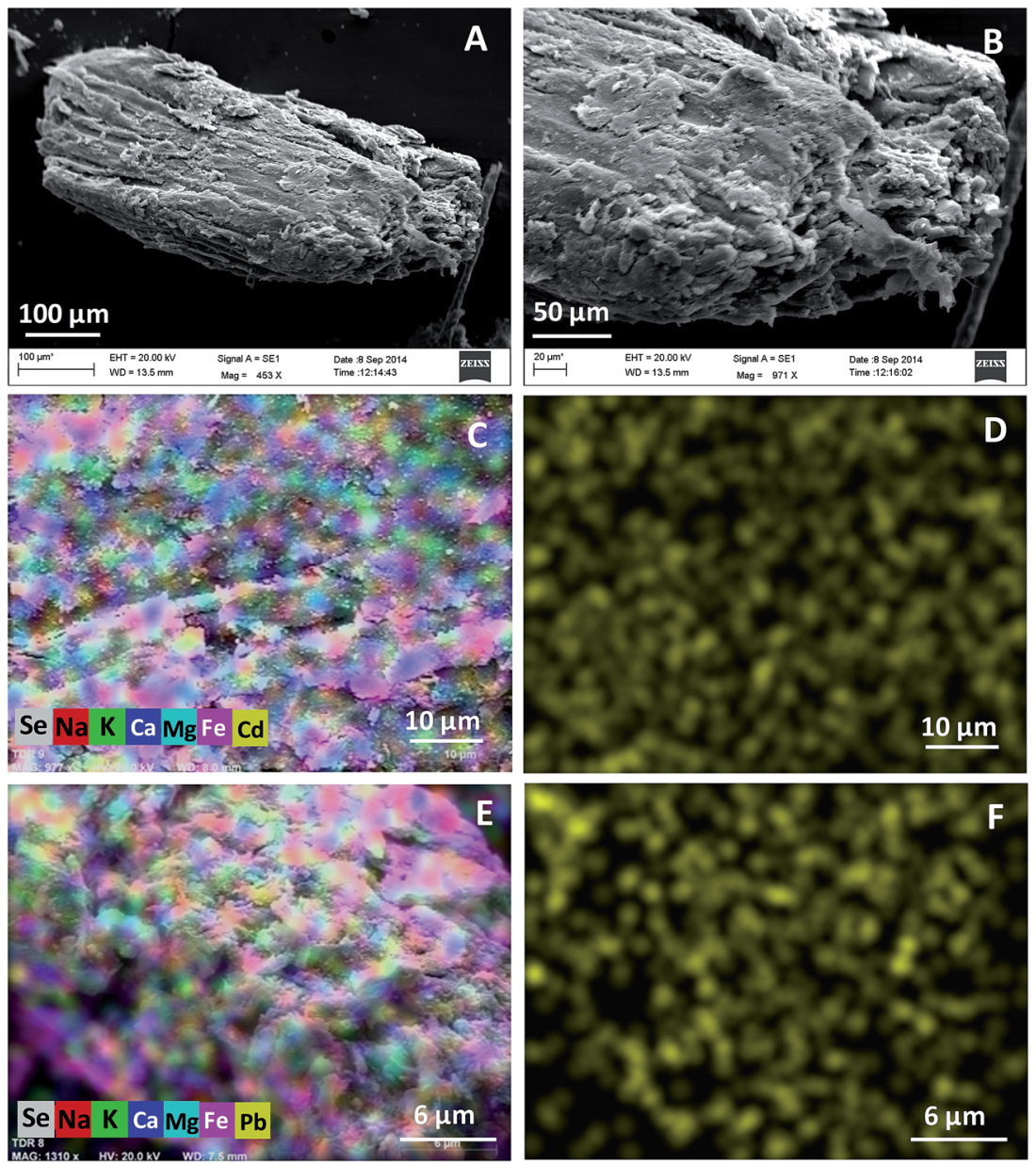

Fig. 5 SEM micrographs of magnetic Kaniar pod powder (MKPP) at (A) $664 \times$ (B) $2.81 \mathrm{k} \times$ and SEM-mapping images of (C) multielements with Cd ${ }^{2+}$ and (D) $\mathrm{Cd}^{2+}(\mathrm{E})$ multielements with $\mathrm{Pb}^{2+}$ and $(\mathrm{F}) \mathrm{Pb}^{2+}$ distribution.
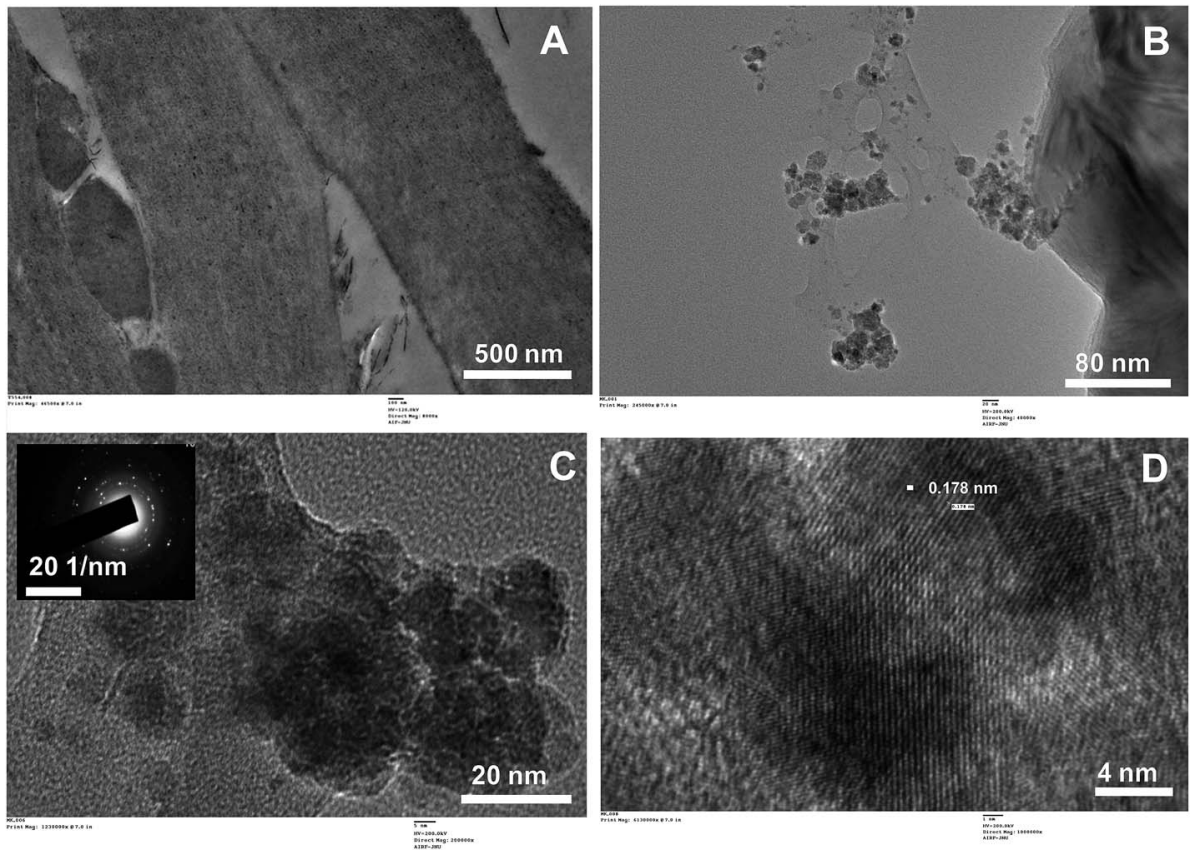

Fig. 6 TEM micrographs of (A) Kaniar pods powder (KPP) and (B-D) magnetic Kaniar pods powder (MKPP) at different magnifications. The inset in the upper left (C) is a SAED pattern and (D) HRTEM micrograph. 

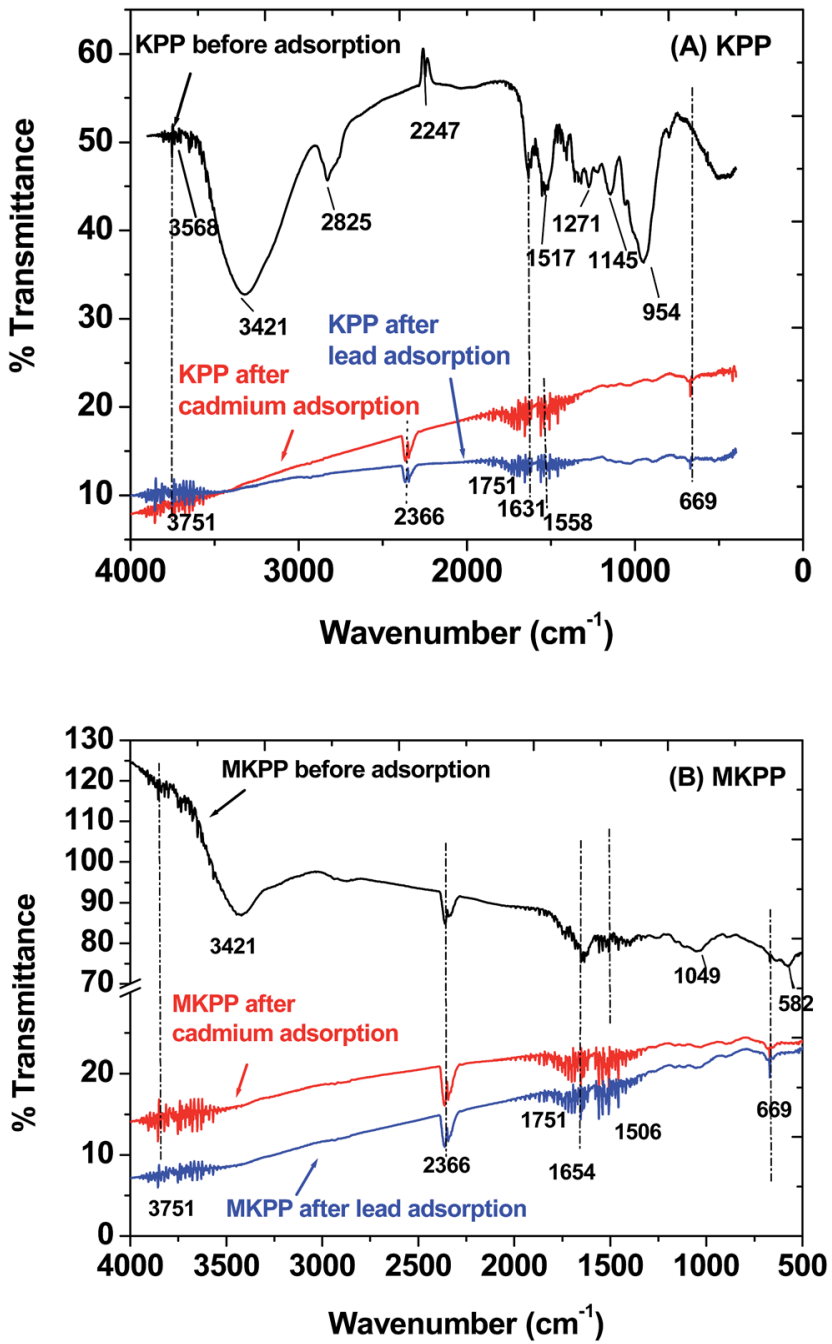

Fig. 7 FTIR spectra of (A) KPP and (B) MKPP before and after $\mathrm{Pb}^{2+}$ and $\mathrm{Cd}^{2+}$ adsorption.

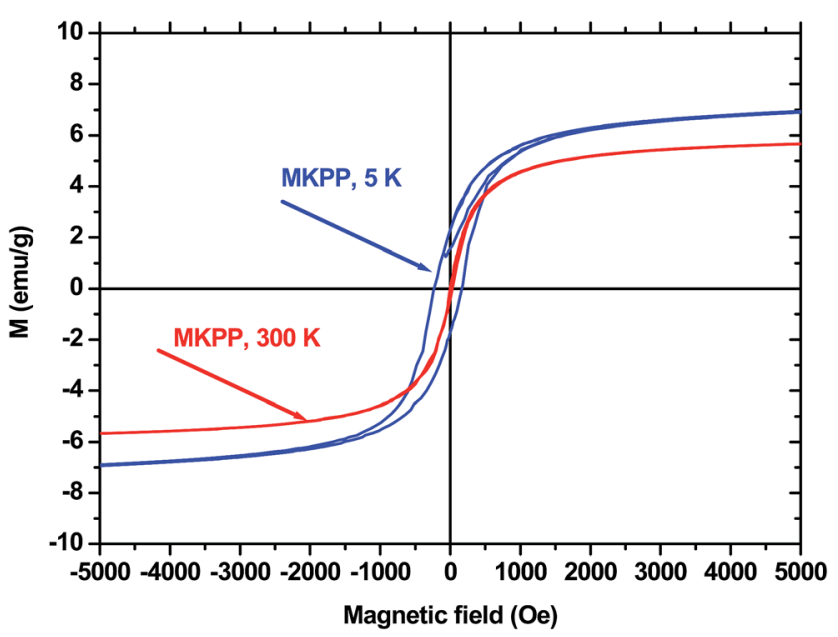

Fig. 8 Magnetic moment of magnetic Kaniar pod powder (MKPP) at 5 $\mathrm{K}$ and $300 \mathrm{~K}$.
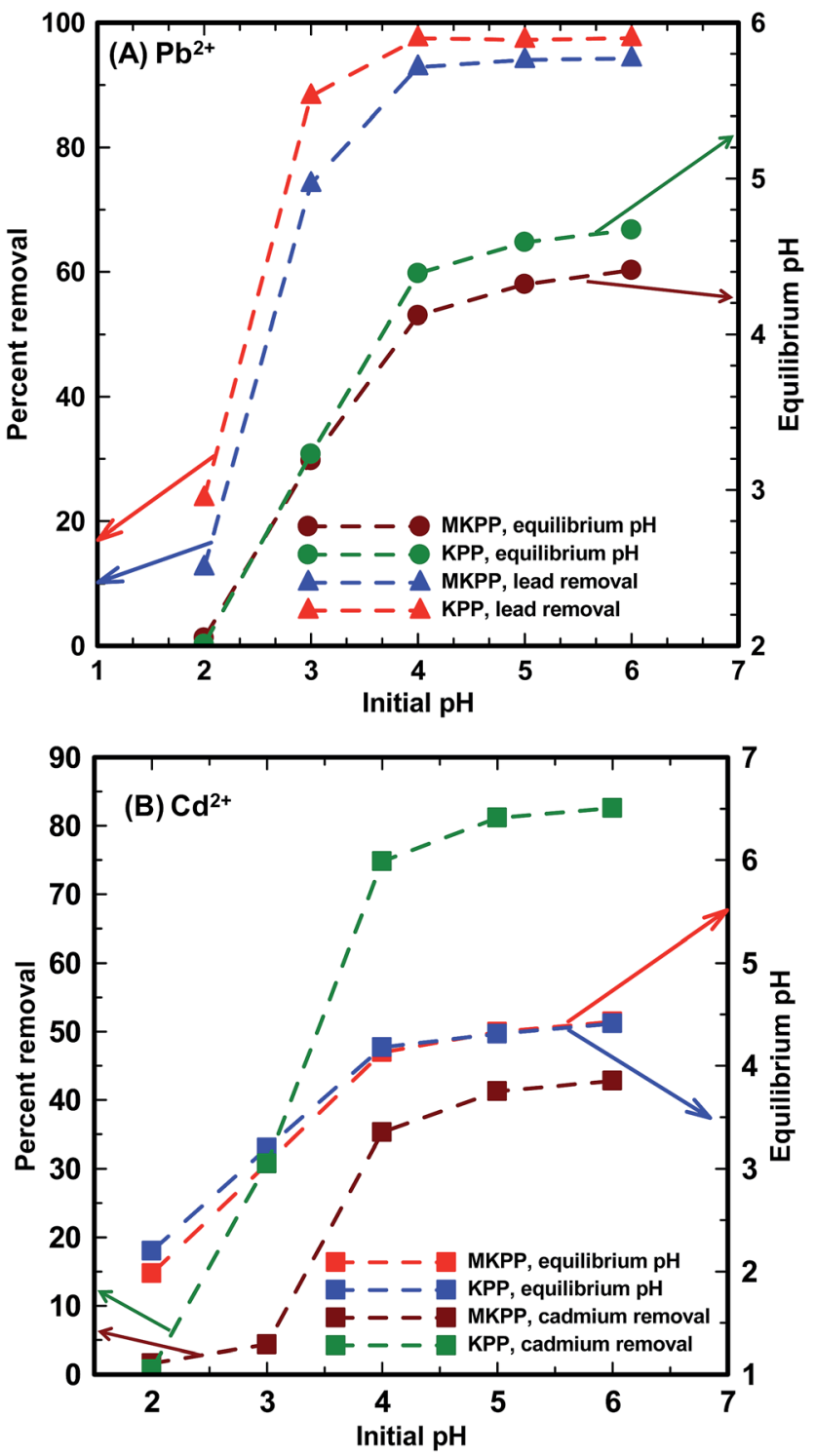

Fig. 9 Effect of $\mathrm{pH}$ on (A) $\mathrm{Pb}^{2+}$ and (B) $\mathrm{Cd}^{2+}$ removal by KPP and MKPP [initial $\mathrm{Pb}^{2+}$ and $\mathrm{Cd}^{2+}$ concentration $=10 \mathrm{mg} \mathrm{L}^{-1}$; adsorbent dose $=2 \mathrm{~g}$ $\mathrm{L}^{-1}$; particle size $=30-50$ B.S.S. mesh; $T=25^{\circ} \mathrm{C}$.

MKPP when $\mathrm{pH}$ rose from 2.0 to 6.0. Similarly, $\mathrm{Cd}^{2+}$ removal went up from 1 to $83 \%$ using KPP and 2 to $43 \%$ using MKPP upon increasing the initial $\mathrm{pH}$ from 2.0 to 6.0. Above the adsorbents' $\mathrm{pH}_{\mathrm{PZC}}$ the surface is negatively charged. Here, much more metal adsorption was observed. When KPP and MKPP was used to adsorb $\mathrm{Pb}^{2+}$ and $\mathrm{Cd}^{2+}$ at $\mathrm{pH}>\mathrm{pH}_{\mathrm{ZPC}}$, the solution equilibrium $\mathrm{pH}$ dropped. This occurs because deprotonation of the adsorbent's acidic functional groups releases $\mathrm{H}_{3} \mathrm{O}^{+}$as metal cations are adsorbed. ${ }^{5,8}$ Therefore, all the kinetic and equilibrium sorption experiments of were carried out at $\mathrm{pH} 4.5$ and 5.0.

\section{3. $\mathrm{Cd}^{2+}$ and $\mathbf{P b}^{2+}$ sorption mechanism}

Agricultural crop residues contain cellulose, lignin, lipids, proteins, simple sugars, starches, functional group-rich compounds that can bind heavy metals. ${ }^{78}$ Specifically, seed pods constituting KPP and MKPP contain a rich variety of secondary metabolite compounds 
<smiles>COc1cc2oc(-c3ccccc3)cc(=O)c2c(O)c1O</smiles><smiles>COc1cc2oc(-c3ccccc3)cc(=O)c2c(O)c1O</smiles>
$\stackrel{M^{2+}}{\longrightarrow}$

$\mathrm{R}=\mathrm{xylosyl}$

Flavone glycoside
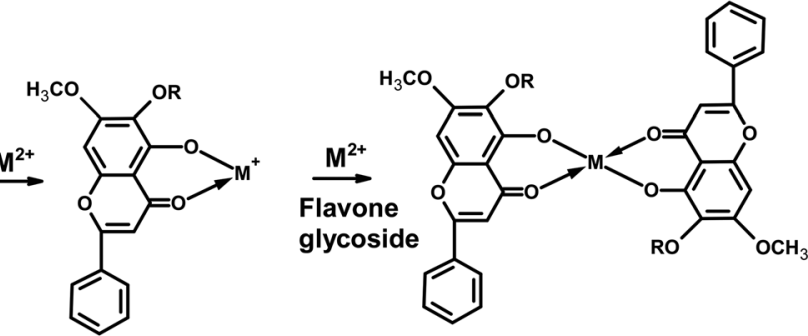<smiles>O=C(CCO)c1c(O)cc2c(c1O)C(=O)[C@@H](O)[C@H](c1ccc(O)c(O)c1)O2</smiles><smiles>[CH]CC</smiles>

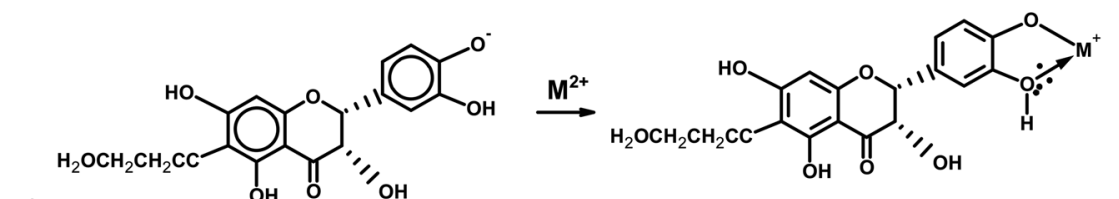<smiles>CO[Ge](C)=[Ge]Cl</smiles><smiles>C1CCCC1</smiles>

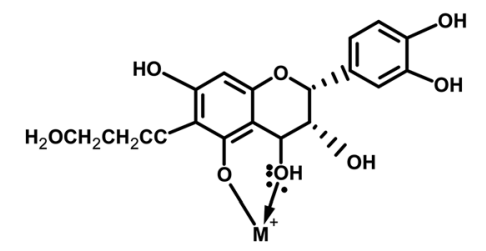<smiles>OCCc1c(O)cc2c(c1O)C(=[W])[C@H](O)[C@H](c1ccc3c(c1)OCO3)O2</smiles><smiles>C#CCNCC(=O)c1cc(C)c(C(C)C)c2ccccc12</smiles>

Surface carboxylic acid

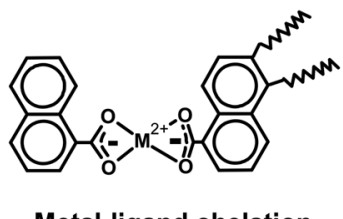

Metal-ligand chelation

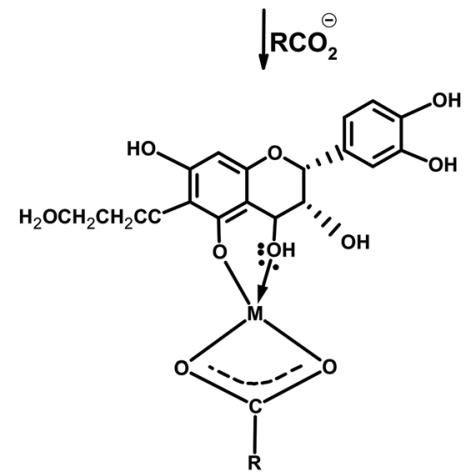

Fig. 10 Example $\mathrm{Pb}^{2+}$ and $\mathrm{Cd}^{2+}$ sorption complexes possible to representative chelating compounds present in KPP and MKPP.

including glycosides, flavenoids, phenolic compounds, oxepins, fatty acids and phytosterols. ${ }^{79}$ We thought these would uniquely contribute to metal chelation and sorption. Previously, mechanisms have been proposed for aqueous $\mathrm{Pb}^{2+}$ and $\mathrm{Cd}^{2+}$ remediation, ${ }^{4,5,80}$ which included electrostatic attraction-repulsion interactions, ion exchange, functional group-metal complex formation, H-bonding, and chelation. ${ }^{81}$ The presence of so many components in Bauhinia purpurea which can chelate metals has focused our attention on the compounds which have been identified in this species as example adsorbents. ${ }^{79}$ Fig. 10 shows two of these more unique specific compounds from Bauhinia purpurea and a surface carboxylic acid as sample adsorption site for either $\mathrm{Pb}^{2+}$ or $\mathrm{Cd}^{2+}$. Of course many other specific adsorption sites exist.

Chelation of $\mathrm{M}^{2+}$ ions are shown by several functions in Fig. 10. $o$-Keto phenol functions in both the xylosyl flavone and taxifolin can singly or doubly chelate $\mathrm{M}^{2+}$ ions with the release of protons to solution. Likewise, the catechol function (shown here (a)

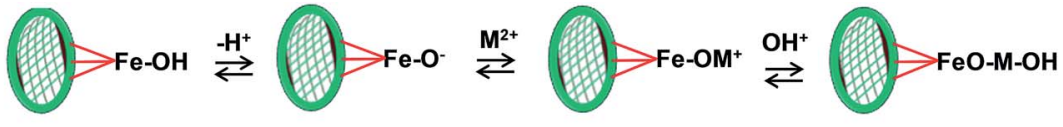

(b)

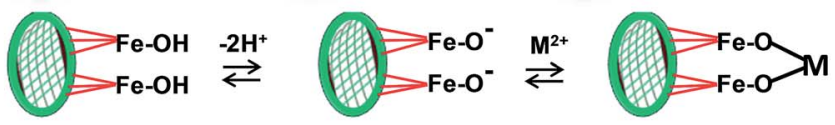

Fig. 11 Adsorption mechanism for $\mathrm{Pb}^{2+}$ and $\mathrm{Cd}^{2+}$ adsorption by MKPP. 


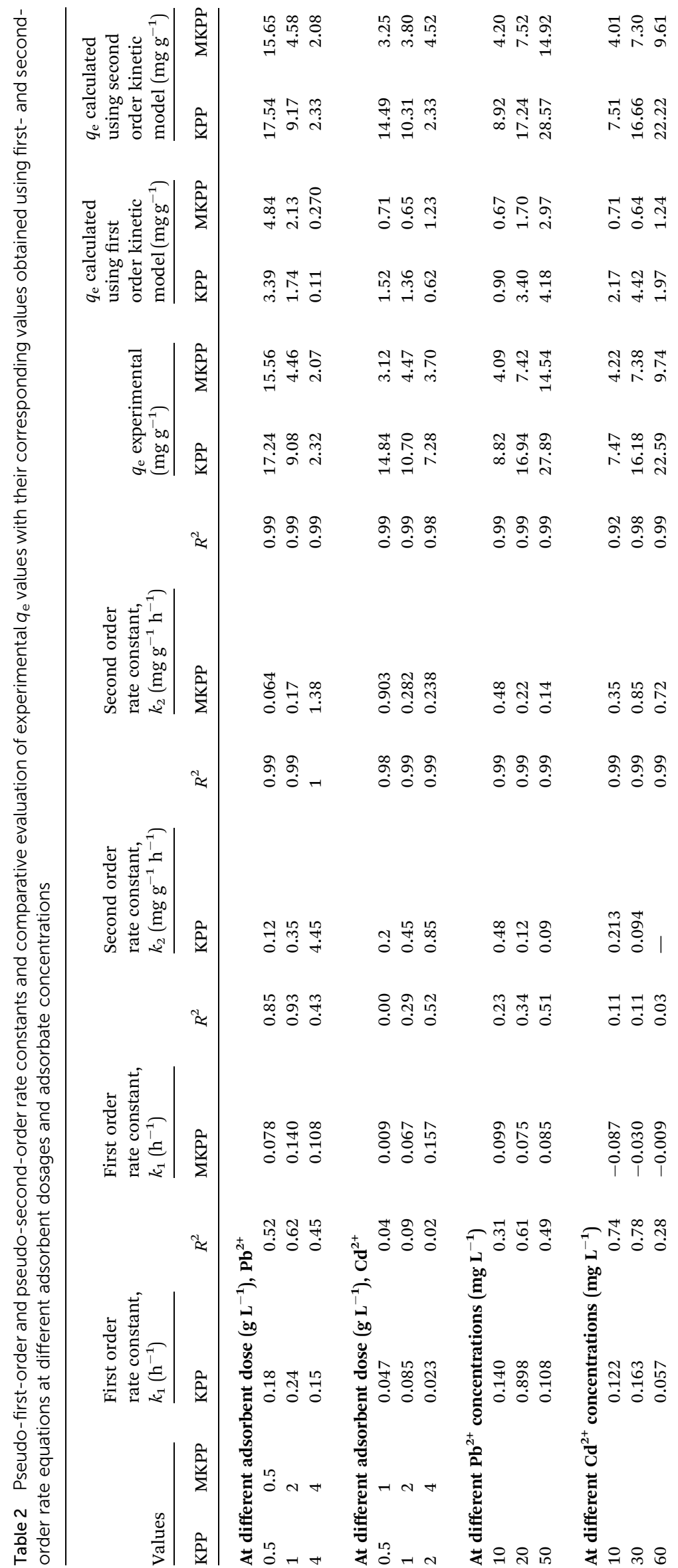


in taxifolin) can chelate to bind either $\mathbf{M}^{2+}$ to generate $\mathbf{M}^{+}$or further to neutral complexes. Alternatively, a single carboxylate can combine with another chelating function to immobilize to metal. Metal-ligand chelation by oxygens is the major interaction in the 4.5-5.0 $\mathrm{pH}$ range. ${ }^{81}$ A possible mechanism for $\mathrm{M}^{2+}$ on the magnetite portion of MKPP is shown in Fig. 11, where surface $\mathrm{Fe}-\mathrm{OH}$ or $\mathrm{Fe}-\mathrm{O}-$ sites actively bind $\mathrm{Cd}^{2+}$ and $\mathrm{Pb}^{2+}$ ions.

\section{4. $\mathrm{Pb}^{2+}$ and $\mathrm{Cd}^{2+}$ sorption dynamics}

The $\mathrm{Pb}^{2+}$ and $\mathrm{Cd}^{2+}$ sorption efficiency as a function of biomass dosage was investigated. Fig. SM5 and SM6 $†$ show the effect of sorbent dose on $\mathrm{Pb}^{2+}$ and $\mathrm{Cd}^{2+}$ removal. Both $\mathrm{Pb}^{2+}$ and $\mathrm{Cd}^{2+}$ uptake increased at higher adsorbent dose, because more adsorption sites were available. A significant jump in $\mathrm{Cd}^{2+}$ removal was observed on increasing KPP dose from 0.5 to $1.0 \mathrm{~g}$ $\mathrm{L}^{-1}$. No further uptake occurred on introducing an additional $1.0 \mathrm{~g} \mathrm{~L}^{-1}$ of KPP (Fig. SM6 $\dagger$ ). Similar behavior was observed for MKPP (Fig. SM6 $\dagger$ ). The maximum sorption percentage achieved by KPP and MKPP reached $96 \%$ and $79 \%$, respectively for $\mathrm{Cd}(\mathrm{II})$ at a biomass concentration of $0.5 \mathrm{~g} \mathrm{~L}^{-1}$. Therefore, 1.0 and $2.0 \mathrm{~g}$ $\mathrm{L}^{-1}$ dosage amounts were selected for KPP and MKPP, respectively in all subsequent equilibrium and dynamic experiments. $\mathrm{Pb}^{2+}$ sorption studies were carried out at $0.1,1.0$ and $4.0 \mathrm{~g} \mathrm{~L}^{-1}$ dosages for KPP and MKPP. Dosage of 1.0 and $2.0 \mathrm{~g} \mathrm{~L}^{-1}$ resulted in $96 \%$ and $97 \% \mathrm{~Pb}^{2+}$ removal by KPP and MKPP, respectively. Further dose increments did not show any further significant uptake. Thus, all dynamic and equilibrium studies were performed at 1.0 and $2.0 \mathrm{~g} \mathrm{~L} \mathrm{~L}^{-1}$ dosage for KPP and MKPP, respectively. The effect of initial $\mathrm{Cd}^{2+}$ and $\mathrm{Pb}^{2+}$ concentrations were investigated $\left(\mathrm{Cd}^{2+}: 10,20\right.$ and $50 \mathrm{mg} \mathrm{L}{ }^{-1} ; \mathrm{Pb}^{2+}: 10,30$ and $\left.60 \mathrm{mg} \mathrm{\textrm {L } ^ { - 1 }}\right) . \mathrm{Cd}^{2+}$ and $\mathrm{Pb}^{2+}$ removal increased on increasing initial adsorbate concentrations, due to the availability of more adsorbate ions and their higher concentrations [Fig. SM7 and SM8 $\dagger$ ]. The effect of temperature was also investigated [Fig. SM9 and SM10†].

Sorption dynamics data were fitted to pseudo-first-order ${ }^{54}$ and second-order ${ }^{55}$ equations (Fig. SM11-SM14 $\dagger$ and Table 2). The pseudo-second-order equation best fit the dynamics data at various adsorbent dosages and initial metal concentrations. Higher correlation coefficients $(>0.99)$ were obtained using the second-order equation (Table 2). Experimental ' $q_{\mathrm{e}}$ ' values were similar to theoretical ' $q$ e' values obtained using pseudo-firstorder equation (Table 2). Similar results were reported for $\mathrm{Pb}(\mathrm{II})^{82}$ and $\mathrm{Zn}$ (II) biosorption. ${ }^{83}$ Therefore, chemisorption was the rate determining step for $\mathrm{Cd}^{2+}$ and $\mathrm{Pb}^{2+}$ removal by KPP and MKPP.

\section{5. $\mathrm{Pb}^{2+}$ and $\mathrm{Cd}^{2+}$ sorption equilibrium}

Sorption equilibrium studies were conducted at $25^{\circ}, 35^{\circ}$ and $45{ }^{\circ} \mathrm{C}$ for $\mathrm{Cd}^{2+}$ (initial $\mathrm{pH}=4.5$ ) and $\mathrm{Pb}^{2+}$ (initial $\mathrm{pH}=5.0$ ) [Fig. 12 and 13]. The initial $\mathrm{Cd}^{2+}$ and $\mathrm{Pb}^{2+}$ concentration range was $2-100 \mathrm{mg} \mathrm{L}^{-1}$ and equilibrium time was $24 \mathrm{~h}$ [Fig. 13 and 14]. Sorption equilibrium data were fitted to Langmuir [Fig. 12 and 13], ${ }^{47}$ Freundlich, ${ }^{46}$ Redlich-Peterson, ${ }^{50}$ Radke-Prausnitz, ${ }^{51}$ Toth, ${ }^{52}$ Koble-Corrigan, ${ }^{53}$ Sips,${ }^{49}$ and Temkin ${ }^{48}$ equations (Table
SM1†) using MATLAB (non-linear least square method) (Fig. SM15-SM18†).

$\mathrm{Cd}^{2+}$ uptake decreased with a temperature rise, whereas $\mathrm{Pb}^{2+}$ removal was generally unaltered by temperature. The Langmuir adsorption isotherm ${ }^{47,84}$ equation described $\mathrm{Pb}^{2+}$ and $\mathrm{Cd}^{2+}$ sorption on both KPP and MKPP, respectively, better than other isotherms. The Langmuir model had high $R^{2}$ [Fig. 12 and 13]. Moreover, Langmuir isotherms were also used to determine a dimensionless constant separation factor $R_{\mathrm{L}}\left[R_{\mathrm{L}}=1 /\left(1+b C_{0}\right) ; R_{\mathrm{L}}\right.$ $>1$ unfavorable; $R_{\mathrm{L}}=1$ linear; $0<R_{\mathrm{L}}<1$ favorable and $R_{\mathrm{L}}=$ 0 irreversible]. $R_{\mathrm{L}}$ predicts whether the adsorption is favorable and unfavorable. ${ }^{85,86}$ The $R_{\mathrm{L}}$ values lie between 0 and 1 indicating that $\mathrm{Pb}^{2+}$ and $\mathrm{Cd}^{2+}$ adsorption on both KPP and MKPP is favorable.

The nonlinear Freundlich adsorption isotherms are given in Fig. SM15 and SM17† while the parameters are reported in Table 3. The $1 / n$ values obtained for $\mathrm{Pb}^{2+}$ and $\mathrm{Cd}^{2+}$ adsorption on KPP and MKPP were between 0.1 and 0.5 , indicating favorable adsorption. Among the three parameter equations, the Sips model best fitted (high $R^{2}$ ) the $\mathrm{Pb}^{2+}$ sorption data on KPP and MKPP (Table 3). Therefore, $\mathrm{Pb}^{2+}$ adsorption on KPP and MKPP
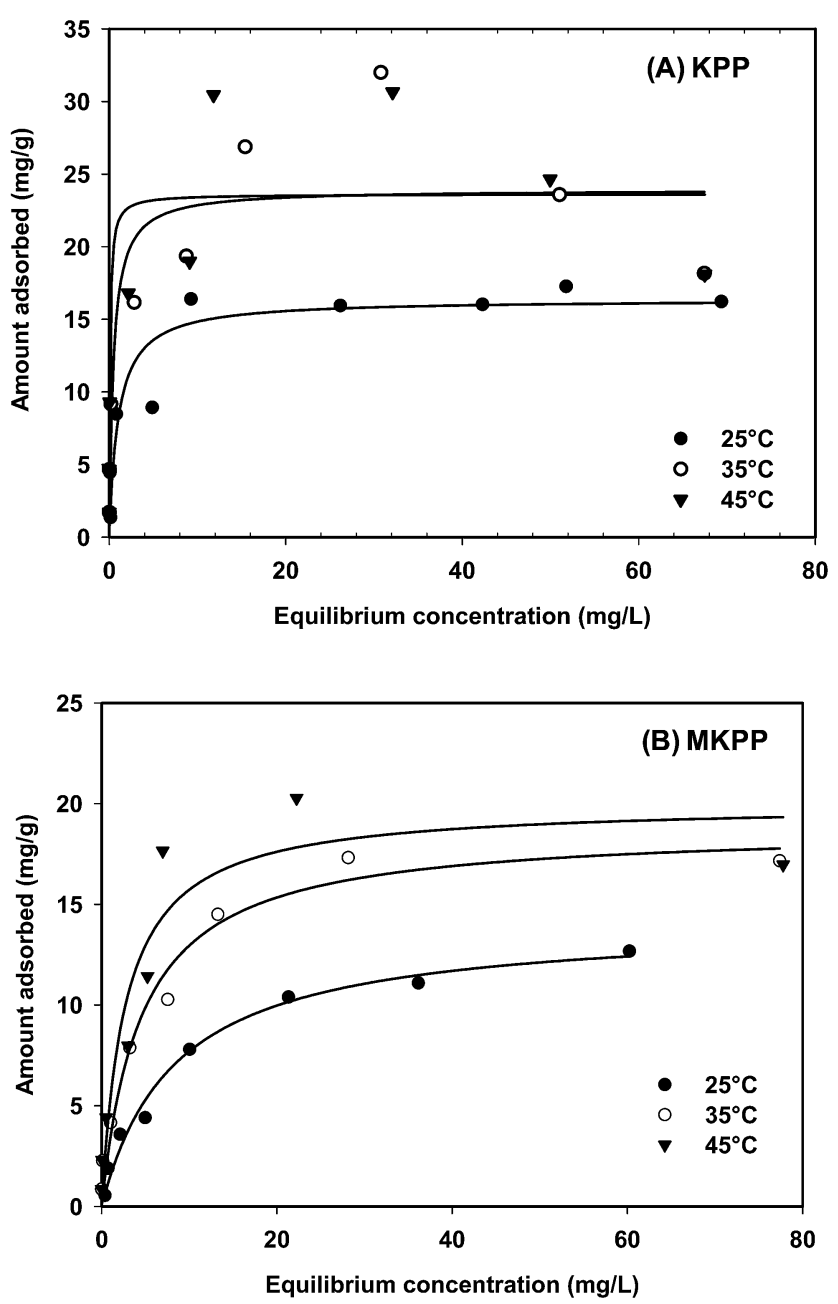

Fig. 12 Langmuir adsorption isotherm of $\mathrm{Pb}^{2+}$ on (A) KPP and (B) MKPP at $25,35,45^{\circ} \mathrm{C}\left[\mathrm{pH}=4.5\right.$; initial $\mathrm{Pb}^{2+}$ concentration range $=2-$ $100 \mathrm{mg} \mathrm{L}^{-1} ; \mathrm{T}=25^{\circ} \mathrm{C}$; adsorbent dose $=1 \mathrm{~g} \mathrm{~L}^{-1}$ (KPP) and $2 \mathrm{~g} \mathrm{~L}^{-1}$ (MKPP); particle size $=30-50$ B.S.S. mesh]. 

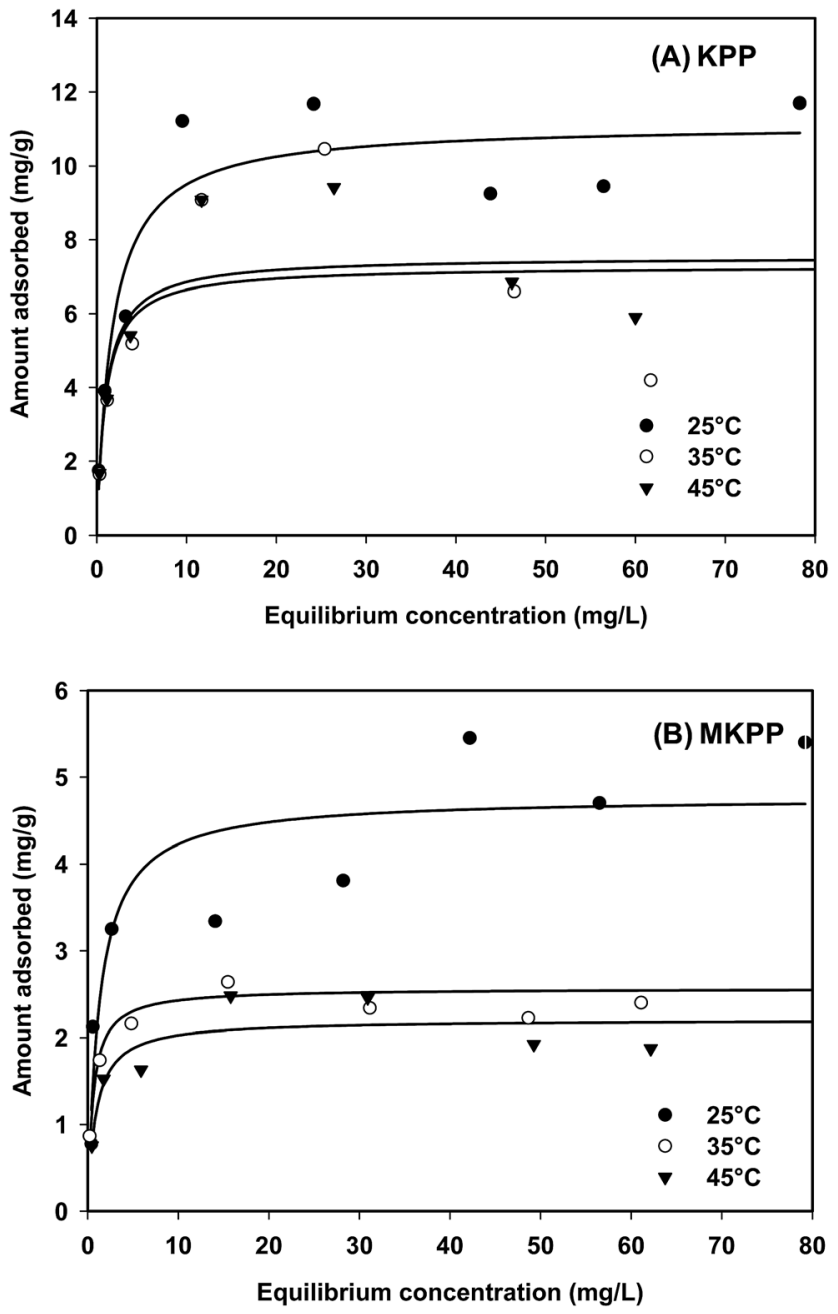

Fig. 13 Langmuir adsorption isotherm of $\mathrm{Cd}^{2+}$ by (A) KPP and (B) MKPP at $25,35,45^{\circ} \mathrm{C}\left[\mathrm{pH}=5.0\right.$; initial $\mathrm{Cd}^{2+}$ concentration range $=2-$ $100 \mathrm{mg} \mathrm{L}^{-1} ; T=25^{\circ} \mathrm{C}$; adsorbent dose $=1 \mathrm{~g} \mathrm{~L}^{-1}$ (KPP) and $2 \mathrm{~g} \mathrm{~L}^{-1}$ (MKPP), particle size $=30-50$ B.S.S. mesh].

was diffusion controlled at low metal-ion concentrations and followed monomolecular adsorption at high concentrations. ${ }^{5}$ Sorption data were also fitted to Redlich-Peterson and RadkePrausnitz equations (Table 3).

\subsection{Thermodynamics behavior}

Studies performed at different temperatures are presented in Fig. 12 and 13.

The amount of $\mathrm{Pb}^{2+}$ adsorption onto both KPP and MKPP increases with a rise in temperature. $\mathrm{Cd}^{2+}$ adsorptions onto KPP and MKPP exhibit the opposite behavior as adsorption diminishes with an increase in temperature. All four processes are spontaneous. $\Delta G^{\circ}$ is negative for $\mathrm{Pb}^{2+}$ and $\mathrm{Cd}^{2+}$ adsorption onto both KPP and MKPP and the thermodynamic parameters are given in Table 4. $\Delta H^{\circ}$ is positive for $\mathrm{Pb}^{2+}$ adsorption on KPP and MKPP, confirming the endothermic nature, while the negative $\Delta H^{\circ}$ obtained for $\mathrm{Cd}^{2+}$ adsorption on KPP and MKPP confirming exothermic nature. Positive $\Delta S^{\circ}$ values for both $\mathrm{Pb}^{2+}$ and $\mathrm{Cd}^{2+}$ adsorption on KPP and MKPP suggested an increase
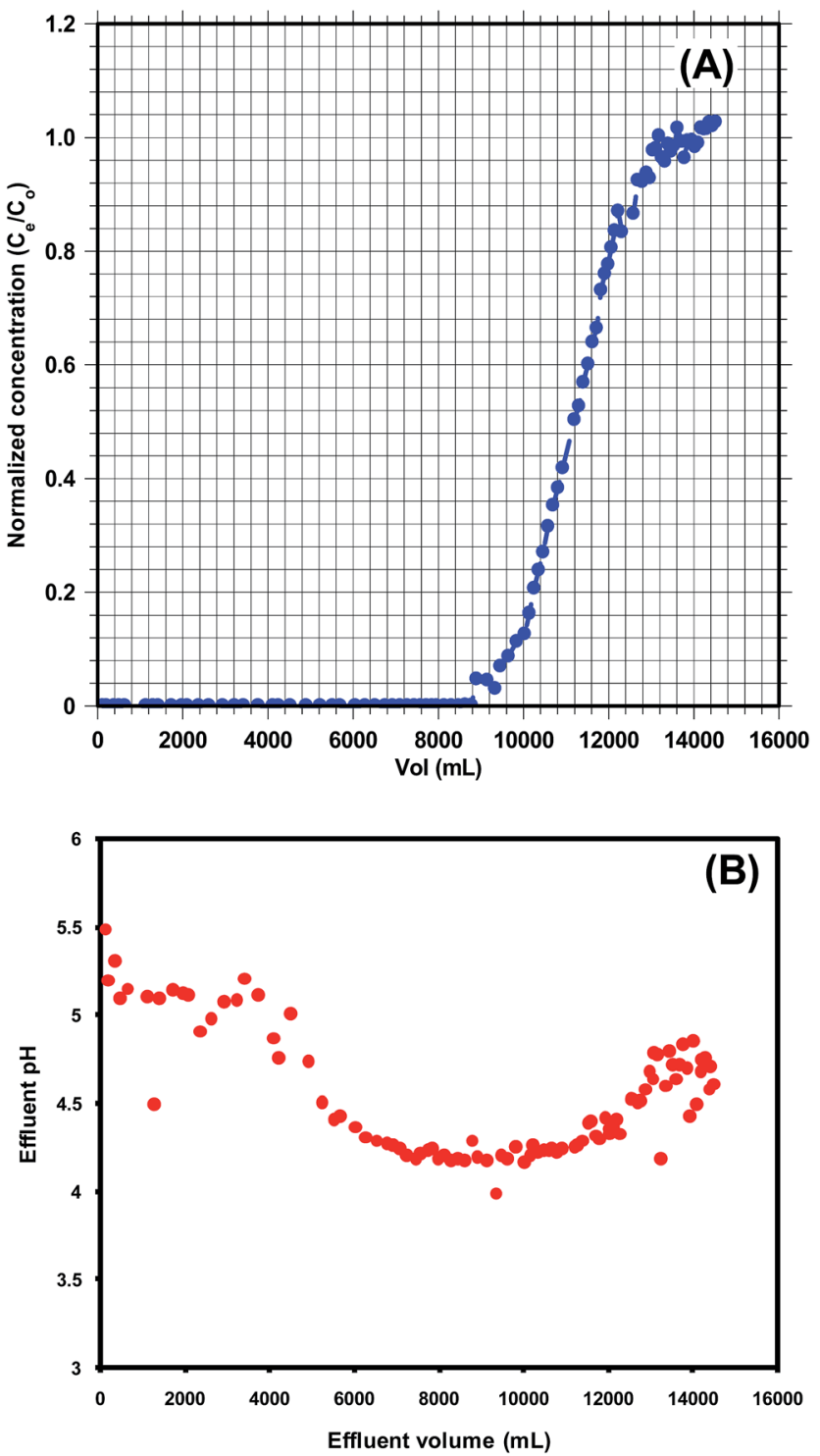

Fig. 14 (A) KPP breakthrough curve (particle size $=30-50$ B.S.S. mesh, $\mathrm{Pb}^{2+}$ concentration $=10 \mathrm{mg} \mathrm{L}^{-1}$, initial $\mathrm{pH}=4.5$ ) and $(B)$ effluent $\mathrm{pH}$ curve for $\mathrm{Pb}^{2+}$ adsorption by KPP.

randomness with some structural or solvation changes occurring at solid/liquid interface. ${ }^{56}$

\section{7. $\mathrm{Cd}^{2+}$ and $\mathrm{Pb}^{2+}$ sorption in a multicomponent system}

Adsorption in multi-component systems is a complex process. Therefore, simultaneous adsorption of $\mathrm{Pb}^{2+}, \mathrm{Cu}^{2+}$, and $\mathrm{Cd}^{2+}$ was carried-out in a ternary system. Adsorption isotherms were obtained at $\mathrm{pH} 4.5$ (KPP) and 5.0 (MKPP) at $25^{\circ} \mathrm{C}$ over a concentration range of $5-150 \mathrm{mg} \mathrm{L}{ }^{-1}$ using a $\mathrm{Pb}^{2+}: \mathrm{Cu}^{2+}: \mathrm{Cd}^{2+}$ ratio of $1: 1: 1$. The percent $\mathrm{Pb}^{2+}$ and $\mathrm{Cd}^{2+}$ removal for KPP and MKPP, respectively, in the ternary system is shown in Fig. SM19 and $\mathrm{SM} 20 . \dagger \mathrm{A} \mathrm{Pb}^{2+}$ removal of $20 \%$ to $80 \%$ and 15 to $50 \%$ for KPP and MKPP was observed, respectively [Fig. SM19 and SM20(A and $\mathrm{B}) \dagger$. Obviously, the presence of both $\mathrm{Cu}^{2+}$ and $\mathrm{Cd}^{2+}$ interfere in $\mathrm{Pb}^{2+}$ adsorption. A similar trend was observed for $\mathrm{Cd}^{2+}(10-$ 
Table 3 Sorption isotherm parameters for $\mathrm{Pb}^{2+}$ and $\mathrm{Cd}^{2+}$ adsorption from water on KPP and MKPP at different temperatures

\begin{tabular}{|c|c|c|c|c|c|c|c|c|c|c|c|c|}
\hline \multirow{2}{*}{$\begin{array}{l}\text { Isotherm } \\
\text { parameters }\end{array}$} & \multicolumn{6}{|l|}{$\mathrm{Pb}^{2+}$} & \multicolumn{6}{|l|}{$\mathrm{Cd}^{2+}$} \\
\hline & \multicolumn{3}{|l|}{ KPP } & \multicolumn{3}{|l|}{ MKPP } & \multicolumn{3}{|l|}{ KPP } & \multicolumn{3}{|l|}{ MKPP } \\
\hline \multicolumn{13}{|l|}{ Freundlich } \\
\hline$K_{\mathrm{F}}\left(\mathrm{mg} \mathrm{g}^{-1}\right)$ & 7.61 & 15.20 & 16.78 & 1.99 & 1.50 & 1.30 & 4.94 & 4.38 & 4.34 & 1.99 & 1.52 & 1.31 \\
\hline \multicolumn{13}{|l|}{ Langmuir } \\
\hline$Q^{\mathrm{o}}\left(\mathrm{mg} \mathrm{g}^{-1}\right)$ & 16.37 & 23.94 & 23.61 & 14.14 & 18.81 & 20.01 & 11.13 & 7.28 & 7.54 & 4.76 & 2.56 & 2.20 \\
\hline$b$ & 0.97 & 2.10 & 11.11 & 0.12 & 0.22 & 0.37 & 0.58 & 1.04 & 1.00 & 0.78 & 1.76 & 1.13 \\
\hline$R^{2}$ & 0.92 & 0.78 & 0.76 & 0.98 & 0.97 & 0.90 & 0.89 & 0.50 & 0.69 & 0.81 & 0.81 & 0.78 \\
\hline$R^{2}$ & 0.90 & 0.80 & 0.78 & 0.98 & 0.97 & 0.90 & 0.88 & 0.52 & 0.70 & 0.86 & 0.91 & 0.77 \\
\hline \multicolumn{13}{|l|}{ Redlich-Peterson } \\
\hline$K_{\mathrm{RP}}\left(\mathrm{L} \mathrm{g}^{-1}\right)$ & 39.68 & 5.87 & 10.30 & 2.21 & 3.96 & 3.48 & 4.16 & 1.65 & 2.29 & 9.60 & 6.95 & 2.05 \\
\hline$a_{\mathrm{RP}}\left(\mathrm{L} \mathrm{mg}^{-1}\right) \beta_{\mathrm{RP}}$ & 3.67 & 0.06 & 0.18 & 0.24 & 0.19 & 0.04 & 0.22 & 0.01 & 0.05 & 3.73 & 3.32 & 0.81 \\
\hline$\beta_{\mathrm{RP}}$ & 0.89 & 1.34 & 1.21 & 0.89 & 1.02 & 1.35 & 1.12 & 1.70 & 1.43 & 0.83 & 0.94 & 1.03 \\
\hline$R^{2}$ & 0.89 & 0.79 & 0.75 & 0.98 & 0.97 & 0.94 & 0.90 & 0.80 & 0.89 & 0.88 & 0.84 & 0.79 \\
\hline \multicolumn{13}{|l|}{ Temkin } \\
\hline$b_{\mathrm{Te}}\left(\mathrm{J} \mathrm{mol}^{-1}\right)$ & 1.15 & 0.96 & 1.20 & 3.42 & 189.50 & 146.45 & 1.53 & 3.20 & 2.99 & 3.43 & 8.91 & 10.67 \\
\hline$a_{\mathrm{Te}}\left(\mathrm{L} \mathrm{mg}^{-1}\right)$ & 47.00 & 260.68 & 2135.41 & 16.14 & 8.90 & 10.67 & 17.41 & 146.91 & 90.23 & 16.15 & 189.49 & 146.45 \\
\hline$R^{2}$ & 0.89 & 0.78 & 0.76 & 0.87 & 0.79 & 0.65 & 0.82 & 0.31 & 0.49 & 0.87 & 0.80 & 0.65 \\
\hline$B_{\mathrm{T}}$ & 0.97 & 2.10 & 11.11 & 0.12 & 0.22 & 0.20 & 0.58 & 1.05 & 1.00 & 0.78 & 1.76 & 1.13 \\
\hline$\beta_{\mathrm{T}}$ & -6.49 & -126.2 & -68.77 & 0.52 & 0.35 & 0.23 & 0.59 & 0.19 & 0.92 & 0.11 & 0.71 & 0.52 \\
\hline$R^{2}$ & 0.86 & 0.78 & 0.76 & 0.98 & 0.96 & 0.90 & 0.89 & 0.50 & 0.69 & 0.81 & 0.82 & 0.78 \\
\hline \multicolumn{13}{|c|}{ Radke and Prausnitz } \\
\hline$A\left(\mathrm{~L} \mathrm{~g}^{-1}\right)$ & 39.68 & 76.28 & 361.60 & 2.20 & $1.46 \times 10^{4}$ & 7.66 & 4.16 & 1.65 & 2.29 & 9.60 & 6.90 & 2.05 \\
\hline$b\left(\left(\mathrm{mg}^{1-\beta} \mathrm{L}^{\beta}\right) \mathrm{g}^{-1}\right)$ & 10.82 & 20.65 & 20.45 & 9.09 & 4.18 & 19.20 & 18.41 & 112.60 & 41.37 & 2.57 & 2.09 & 2.53 \\
\hline$\beta$ & 0.11 & 0.04 & 0.05 & 0.10 & 0.36 & 0.01 & -0.13 & -0.70 & -0.43 & 0.16 & 0.05 & -0.03 \\
\hline$R^{2}$ & 0.89 & 0.79 & 0.77 & 0.98 & 0.87 & 0.90 & 0.90 & 0.80 & 0.89 & 0.88 & 0.84 & 0.79 \\
\hline
\end{tabular}

Table 4 Thermodynamic parameters for $\mathrm{Pb}^{2+}$ and $\mathrm{Cd}^{2+}$ adsorption on KPP and MKPP

\begin{tabular}{|c|c|c|c|c|c|c|c|c|c|c|}
\hline \multirow{3}{*}{$\begin{array}{l}\text { Metal } \\
\text { ions }\end{array}$} & \multicolumn{5}{|l|}{ KРP } & \multicolumn{5}{|l|}{ МKРP } \\
\hline & \multicolumn{3}{|c|}{$\Delta G^{\circ}\left(\mathrm{kJ} \mathrm{mol}^{-1}\right)$} & \multirow{2}{*}{$\begin{array}{l}\Delta H^{\circ} \\
\left(\mathrm{kJ} \mathrm{mol}^{-1}\right)\end{array}$} & \multirow{2}{*}{$\begin{array}{l}\Delta S^{\circ} \\
\left(\mathrm{kJ} \mathrm{mol}^{-1} \mathrm{~K}^{-1}\right)\end{array}$} & \multicolumn{3}{|c|}{$\Delta G^{\circ}\left(\mathrm{kJ} \mathrm{mol}^{-1}\right)$} & \multirow{2}{*}{$\begin{array}{l}\Delta H^{\circ} \\
\left(\mathrm{kJ} \mathrm{mol}^{-1}\right)\end{array}$} & \multirow{2}{*}{$\begin{array}{l}\Delta S^{\circ} \\
\left(\mathrm{kJ} \mathrm{mol}^{-1} \mathrm{~K}^{-1}\right)\end{array}$} \\
\hline & $25{ }^{\circ} \mathrm{C}$ & $35^{\circ} \mathrm{C}$ & $45^{\circ} \mathrm{C}$ & & & $25^{\circ} \mathrm{C}$ & $35^{\circ} \mathrm{C}$ & $45^{\circ} \mathrm{C}$ & & \\
\hline $\mathrm{Pb}^{2+}$ & -34.2 & -37.3 & -42.9 & 59.1 & 0.31 & -29.0 & -31.5 & -33.9 & 46.9 & 0.25 \\
\hline $\mathrm{Cd}^{2+}$ & -32.9 & -35.4 & -36.6 & -3.6 & 0.10 & -33.6 & -36.8 & -36.9 & -35.9 & 0.003 \\
\hline
\end{tabular}


Table $5 \mathrm{~Pb}^{2+}$ and $\mathrm{Cd}^{2+}$ removal from contaminated groundwater sample using KPP and MKPP (adsorbent dose $1.0 \mathrm{~g} \mathrm{~L}^{-1}$ (KPP) and $2.0 \mathrm{~g} \mathrm{~L}^{-1}$ (MKPP), equilibrium time $48 \mathrm{~h} ; \mathrm{pH} 4.5\left(\mathrm{~Pb}^{2+}\right)$ and $5.0\left(\mathrm{Cd}^{2+}\right)$; temperature $\left.25^{\circ} \mathrm{C}\right)$

\begin{tabular}{|c|c|c|c|c|c|c|}
\hline \multirow[b]{2}{*}{ Parameters } & \multicolumn{3}{|l|}{$\mathrm{Pb}^{2+}$} & \multicolumn{3}{|l|}{$\mathrm{Cd}^{2+}$} \\
\hline & $\begin{array}{l}\text { Initial } \\
\text { concentration }\end{array}$ & $\begin{array}{l}\text { Concentration } \\
\text { after treatment } \\
\text { with KPP }\end{array}$ & $\begin{array}{l}\text { Concentration } \\
\text { after treatment } \\
\text { with MKPP }\end{array}$ & $\begin{array}{l}\text { Initial } \\
\text { concentration }\end{array}$ & $\begin{array}{l}\text { Concentration } \\
\text { after treatment } \\
\text { with KPP }\end{array}$ & $\begin{array}{l}\text { Concentration } \\
\text { after treatment } \\
\text { with MKPP }\end{array}$ \\
\hline $\mathrm{Pb}^{2+}\left(\mathrm{mg} \mathrm{L}^{-1}\right)$ & 42.81 & 31.24 & 27.81 & - & - & - \\
\hline $\mathrm{Cd}^{2+}\left(\mathrm{mg} \mathrm{L}^{-1}\right)$ & - & - & - & 48.65 & 38.24 & 37.36 \\
\hline Salinity (ppt) & 1.8 & 1.8 & 1.9 & 0.5 & 0.5 & 0.5 \\
\hline TDS $\left(\mathrm{mg} \mathrm{L}^{-1}\right)$ & 1683 & 1706 & 1746 & 514 & 526 & 535 \\
\hline $\mathrm{Na}^{+}\left(\mathrm{mg} \mathrm{L}^{-1}\right)$ & 69.9 & 56.1 & 66.5 & 66.7 & 13.8 & 15.3 \\
\hline $\mathrm{K}^{+}\left(\mathrm{mg} \mathrm{L}^{-1}\right)$ & 3.5 & 2.9 & 2.9 & 2.7 & 0.1 & 0.2 \\
\hline $\mathrm{Ca}^{2+}\left(\mathrm{mg} \mathrm{L}^{-1}\right)$ & 16.68 & 16.7 & 20 & 17.56 & 8.2 & 8 \\
\hline $\mathrm{Mg}^{2+}\left(\mathrm{mg} \mathrm{L}^{-1}\right)$ & 50.05 & 48.6 & 48.93 & 50.03 & 49.59 & 48.93 \\
\hline
\end{tabular}

90\% for KPP and 10-80\% for MKPP) [Fig. SM19 and SM20(A and $\mathrm{B}) \dagger$. More interference was observed for $\mathrm{Cd}^{2+}$ adsorption for this ternary system in the high concentration range. Overall, copper is expected to compete vigorously with both $\mathrm{Pb}^{2+}$ and $\mathrm{Cd}^{2+}$ for adsorption sites. It exhibits similar columbic responses and four-coordinate complexation chemistries with $\mathrm{Pb}^{2+}$ and $\mathrm{Cd}^{2+}$.

\section{8. $\mathbf{P b}^{2+}$ and $\mathrm{Cd}^{2+}$ removal from actual groundwater}

Natural water systems contain a complex mixture of ions. These may also interfere with $\mathrm{Pb}^{2+}$ or $\mathrm{Cd}^{2+}$ during adsorption on KPP and MKPP. Thus, $\mathrm{Pb}^{2+}$ or $\mathrm{Cd}^{2+}$ removal from groundwater samples, collected from Khekra Village, Baghpat District, Uttar Pradesh, India, by KPP and MKPP was investigated. The physicochemical characteristics of this groundwater are shown in Table 5. An additional $50 \mathrm{mg} \mathrm{L}{ }^{-1}$ of either $\mathrm{Cd}^{2+}$ or $\mathrm{Pb}^{2+}$ was spiked into this water sample. Initial $\mathrm{pHs}$ were adjusted to 4.5 and 5.0 for $\mathrm{Pb}^{2+}$ and $\mathrm{Cd}^{2+}$, respectively. A predetermined dose of KPP $\left(1 \mathrm{~g} \mathrm{~L}^{-1}\right)$ or MKPP $\left(2 \mathrm{~g} \mathrm{~L}^{-1}\right)$ was added to each sample. After $48 \mathrm{~h}$, the samples were filtered and the $\mathrm{Cd}^{2+}$ and $\mathrm{Pb}^{2+}$

Table 6 Fixed bed parameters for $\mathrm{Pb}^{2+}$ adsorption by KPP

\begin{tabular}{|c|c|}
\hline Parameters & Values \\
\hline$C_{0}\left(\mathrm{mg} \mathrm{mL}^{-1}\right)$ & 0.00822 \\
\hline$C_{\mathrm{x}}\left(\mathrm{mg} \mathrm{mL}^{-1}\right)$ & 0.00793 \\
\hline$C_{\mathrm{b}}\left(\mathrm{mg} \mathrm{mL}^{-1}\right)$ & 0.00026 \\
\hline$V_{\mathrm{x}}\left(\mathrm{mg} \mathrm{cm} \mathrm{cm}^{-2}\right)$ & 33.36 \\
\hline$V_{\mathrm{b}}\left(\mathrm{mg} \mathrm{cm} \mathrm{cm}^{-2}\right)$ & 0.74 \\
\hline$F_{\mathrm{m}}\left(\mathrm{mg} \mathrm{cm} \mathrm{cm}^{-2} \mathrm{~min}^{-1}\right)$ & 0.01 \\
\hline$D(\mathrm{~cm})$ & 6 \\
\hline$t_{\mathrm{x}}(\min )$ & 3092 \\
\hline$t_{\delta}(\min )$ & 3023 \\
\hline$t_{\mathrm{b}}(\min )$ & 2216 \\
\hline$F$ & 0.27 \\
\hline$\delta(\mathrm{cm})$ & 1.7 \\
\hline Saturation (\%) & 79.23 \\
\hline Usage rate $\left(\mathrm{kg} \mathrm{L}^{-1}\right)$ & 0.0005 \\
\hline $\mathrm{EBCT}(\mathrm{min})$ & 5.56 \\
\hline
\end{tabular}
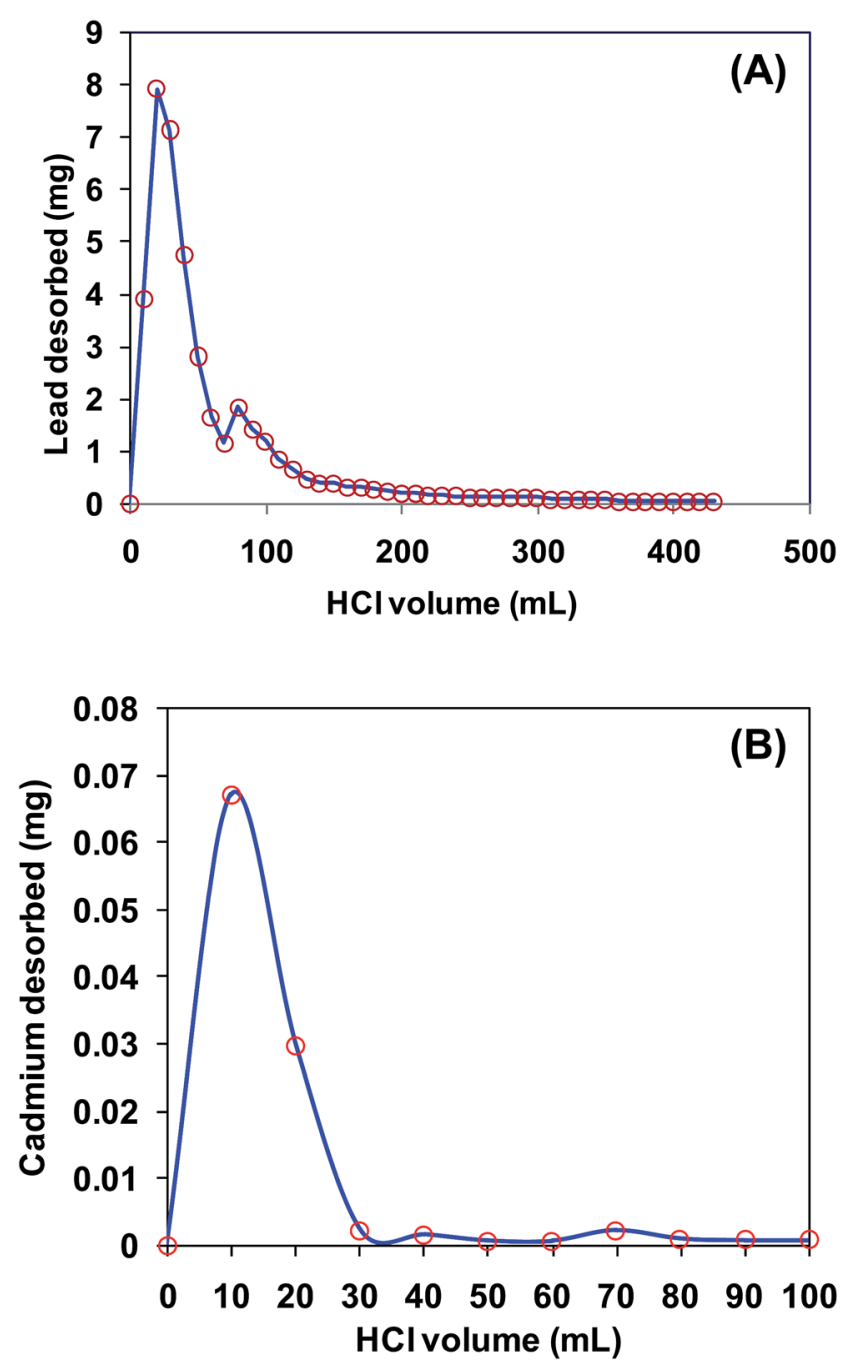

Fig. 15 KPP desorption curves for (a) $\mathrm{Pb}^{2+}$ and (b) $\mathrm{Cd}^{2+}$ using $0.1 \mathrm{~N}$ $\mathrm{HCl}$. 
concentrations analyzed. $\mathrm{Cd}^{2+}$ and $\mathrm{Pb}^{2+}$ concentrations were reduced by adsorption (Table 5), showing both KPP and MKPP could be successfully removed $\mathrm{Cd}^{2+}$ and $\mathrm{Pb}^{2+}$ from groundwater.

\subsection{Column studies}

3.9.1. Fixed-bed $\mathrm{Pb}^{2+}$ sorption and desorption studies. $\mathrm{Pb}^{2+}$ removal using a fixed-bed of KPP was studied. The column set-up is shown in Fig. SM1. $\dagger$ To an acrylic column (length $=40 \mathrm{~cm}$; diameter $=20 \mathrm{~mm}) 5 \mathrm{~g}$ KPP $(30-50$ B.S.S. mesh $)$ was added, supported by glass wool. The KPP bed height was $6 \mathrm{~cm}$. A Pb solution (conc. $=10 \mathrm{mg} \mathrm{L}^{-1}$ ) passed continuously through under gravity@5 $\mathrm{mL} \mathrm{min}^{-1}$ until the exhaustion point was reached. The breakthrough curve expressed in terms of $C / C_{0}$ versus the sorption volume of aqueous $\mathrm{Pb}^{2+}$ on KPP is shown in Fig. $14 .^{87,88}$ The total time involved for establishment of primary adsorption zone $\left(t_{\mathrm{x}}\right)$ (eqn (10)), the time for the primary adsorption zone (PAZ) to move down its length $\left(t_{\delta}\right)$ (eqn (11)), the length of the primary adsorption zone $(\delta)$ (eqn (12)), the fractional capacity $(f)$ (eqn (13)), the bed depth $(D)$ (eqn (14)), the time required for initial PAZ formation $\left(t_{\mathrm{b}}\right)$ (eqn (12)-(14)), the mass rate of flow to the adsorber $\left(F_{\mathrm{m}}\right)$ (eqn (11)), the percent saturation of column at breakthrough (eqn (15)) were obtained. The bed volume (eqn (16)), the empty-bed-contact-time (EBCT) (eqn (17)) and the biomass usage rate (eqn (18)) were also calculated. Table 6 lists the values of these fixed bed column parameters. ${ }^{87}$

$$
\begin{gathered}
t_{\mathrm{x}}=\frac{\bar{V}_{\mathrm{x}}}{F_{\mathrm{m}}} \\
t_{\delta}=\frac{\bar{V}_{\mathrm{x}}-\bar{V}_{\mathrm{b}}}{F_{\mathrm{m}}} \\
\frac{\delta}{D}=\frac{t_{\delta}}{t_{\mathrm{x}}-t_{\mathrm{b}}} \\
f=1-\frac{t_{\mathrm{b}}}{t_{\delta}} \\
\delta=D\left(1-\frac{t_{\mathrm{b}}}{t_{\mathrm{x}}}\right)
\end{gathered}
$$

Table 7 Comparison of Langmuir adsorption capacities of KPP and MKPP versus other biosorbents for $\mathrm{Pb}^{2+}$ and $\mathrm{Cd}^{2+}$ remediation from water

\begin{tabular}{lllll}
\hline \multirow{2}{*}{ Biosorbent } & $\begin{array}{l}\text { Initial } \\
\mathrm{pH}\end{array}$ & $\begin{array}{l}\text { Temp. } \\
\left({ }^{\circ} \mathrm{C}\right)\end{array}$ & $\begin{array}{l}\text { Conc. range } \\
\left(\mathrm{mg} \mathrm{L}^{-1}\right)\end{array}$ & $\begin{array}{l}\text { Langmuir adsorption } \\
\text { capacity }\left(\mathrm{mg} \mathrm{g}^{-1}\right)\end{array}$ \\
\hline
\end{tabular}

\section{$[\mathrm{A}] \mathbf{P b}^{2+}$}

KPP

MKPP

Banana peels

Ground nut husk modified with Gaur gum

Eupatorium adenophorum Spreng

Poplar tree branch

Pomegranate peel

Saccharomyces cerevisiae

S. polyrhiza biomass

Polyamic acid grafted bakers's yeast biomass

Nitrilotriacetic acid anhydride modified ligno-cellulosic material

Waste biomass from biotrickling filters

$[\mathrm{B}] \mathrm{Cd}^{2+}$

KPP

MKPP

Moringa oleifera Lamarck seed

Rice husk

Coconut copra

Caulerpa lentillifera

Eucalyptus bark

Banana peels

Saccharomyces cerevisiae

S. polyrhiza biomass

Polyamic acid grafted bakers's yeast biomass

Nitrilotriacetic acid anhydride modified ligno-cellulosic material
5.0

3.0

-

4.0

-

3.8

4.5
4.5
5.0
5.0
5.0
4.0
5.6
-
4.0
-
4.0

5.0

5.0

5.0

6.5

6.6-6.8

6.0

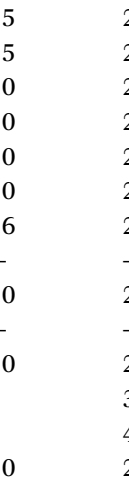

$\begin{array}{ll}5-100 & 16.37 \\ 5-100 & 14.14 \\ 30-80 & 2.2 \\ 20-100 & 9.8 \\ 10-50 & 3.5 \\ 1-10 & 1.7 \\ 10-50 & 13.9 \\ - & 41.9 \\ 100-160 & 124.0 \\ - & 204.5 \\ 20-600 & 304 \\ & 309 \\ 10-200 & 326 \\ & 160\end{array}$

This study This study

$-$

10.5-201

-

100-160

20-500

96 


$$
\text { Percent saturation }=\frac{D+\delta(f-1)}{D} \times 100
$$

$$
\begin{gathered}
\text { Bed volume }=\frac{\text { weight of biomass }(\mathrm{kg})}{\text { biomass bulk density }\left(\mathrm{kg} \mathrm{m}^{-3}\right)} \\
\mathrm{EBCT}=\frac{\text { bed volume }}{\text { flow rate }}
\end{gathered}
$$

Biomass usage rate $\left(\mathrm{kg} \mathrm{L}^{-1}\right)$

$$
=\frac{\text { weight of biomass in column }(\mathrm{g})}{\text { volume of breakthrough }(\mathrm{L})}
$$

here, $V_{\mathrm{b}}$ and $V_{\mathrm{x}}$ are total effluent mass quantity per unit adsorbent area at the breakpoint, and the total effluent mass quantity per unit adsorbent area when adsorbent is approaching saturation, respectively. $C_{\mathrm{b}}$ and $C_{\mathrm{x}}$ are the effluent concentrations at $V_{\mathrm{b}}$ and $V_{\mathrm{x}}$, respectively. The performance in a packed column can be characterized by the shape of the breakthrough curve. ${ }^{87,88}$ An ' $\mathrm{S}$ ' shaped breakthrough curve was obtained for $\mathrm{Pb}^{2+}$ sorption on KPP (Fig. 14).

The column capacity was slightly higher $\left(18.8 \mathrm{mg} \mathrm{g}^{-1}\right)$ than batch capacity $\left(16.4 \mathrm{mg} \mathrm{g}^{-1}\right.$ ) for $\mathrm{Pb}^{2+}$ removal. This is because a large $\mathrm{Pb}^{2+}$ concentration gradient is continuously present at KPP interface.

$\mathrm{pH}$ changes occurred during column experiments. The equilibrium $\mathrm{pH}$ initially increased to 5.5 , possibly because of adsorption of the $\mathrm{H}_{3} \mathrm{O}^{+}$from the solution. Furthermore, equilibrium $\mathrm{pH}$ decreased to $\mathrm{pH} 3.99$ at the breakpoint as the column attained saturation, where no more $\mathrm{H}_{3} \mathrm{O}^{+}$adsorption occurred (Fig. 14). At the exhaustion point, the equilibrium $\mathrm{pH}$ was similar to the initial pH (4.5) (Fig. 14). This confirmed that no further $\mathrm{Pb}^{2+}$ uptake occurred beyond the exhaustion point. Similar observations were reported earlier. ${ }^{89}$

Lead desorption from KPP was performed using $10 \mathrm{~mL}$ increments of $0.1 \mathrm{~N} \mathrm{HCl}$ at the same flow rate and bed height (Fig. 15). About $85 \%$ of total $\mathrm{Pb}^{2+}$ desorption was achieved using first ten aliquots (total $100 \mathrm{~mL}$ ) of $\mathrm{HCl}$. The remaining $\mathrm{Pb}^{2+}$ was desorbed in successive increments.

Cadmium desorption was performed in batch mode using 10 $\mathrm{mL}$ increments of $0.1 \mathrm{~N} \mathrm{HCl}$. Initially, $50 \mathrm{~mL}$ of $100 \mathrm{mg} \mathrm{L}^{-1} \mathrm{Cd}^{2+}$ solution (pH 5.0) was agitated with $4 \mathrm{~g} \mathrm{~L}^{-1} \mathrm{KPP}$ for $24 \mathrm{~h}$ (Fig. 15). The suspension was then filtered and KPP biosorbent was desorbed using $10 \mathrm{~mL} 0.1 \mathrm{~N} \mathrm{HCl}$. Approximately $63 \%$ of the total cadmium desorption was achieved in first 10 aliquot (total 10 $\mathrm{mL}$ ) of $\mathrm{HCl}$. The KPP and MKPP biosorbents were highly stable under acidic aqueous medium. Both KPP and MKPP samples were suspended in acidic water $(0.1,0.2,0.5,1$ and $2 \mathrm{~N} \mathrm{HCl})$. No significant leaching of iron was observed during the period of twelve hours.

\section{Conclusions}

Bauhinia purpurea (Kaniar) pods were dried, powdered and utilized for cadmium and lead removal. Bauhinia purpurea (Kaniar) pod powders (KPP) were converted into magnetic Bauhinia purpurea (Kaniar) powders (MKPP) by magnetite precipitation onto KPP. KPP and MKPP were characterized and used for $\mathrm{Cd}^{2+}$ and $\mathrm{Pb}^{2+}$ sorptive removal. Optimum removal occurred at $\mathrm{pH} 5.0$ and 4.5 for $\mathrm{Cd}^{2+}$ and $\mathrm{Pb}^{2+}$, respectively. $\mathrm{Cd}^{2+}$ and $\mathrm{Pb}^{2+}$ sorption mechanisms were established. Sorption equilibrium and dynamic studies were conducted. Among two parameter models, the Langmuir equation best described $\mathrm{Cd}^{2+}$ and $\mathrm{Pb}^{2+}$ adsorption, with capacities of 11.1 and $4.8 \mathrm{mg} \mathrm{g}^{-1}$ for $\mathrm{Cd}^{2+}$ and 24.0 and $20.0 \mathrm{mg} \mathrm{g}^{-1}$ for $\mathrm{Pb}^{2+}$ obtained on KPP and MKPP, respectively. Among three parameter models, RedlichPeterson and Radke-Prausnitz equations were best fitted to $\mathrm{Cd}^{2+}$ sorption and Sips model best fitted to $\mathrm{Pb}^{2+}$ sorption data. Langmuir adsorption capacities of KPP and MKPP for $\mathrm{Pb}^{2+}$ and $\mathrm{Cd}^{2+}$ were comparable to other biosorbents (Table 7). Sorption dynamics data was obtained and best fitted to pseudo-second order kinetics for $\mathrm{Cd}^{2+}$ and $\mathrm{Pb}^{2+}$. Chemisorption was the rate controlling mechanism. Adsorption thermodynamics parameters were calculated (Table 4). $\mathrm{Cd}^{2+}$ and $\mathrm{Pb}^{2+}$ adsorption was spontaneous. $\mathrm{Cd}^{2+}$ adsorption was exothermic whereas $\mathrm{Pb}^{2+}$ sorption was endothermic as evidenced by the $\Delta H^{\circ}$ values. $\mathrm{Cd}^{2+}$ and $\mathrm{Pb}^{2+}$ were successfully removed in a multi-ion aqueous environment of $\mathrm{Cd}^{2+}, \mathrm{Pb}^{2+}$, and $\mathrm{Cu}^{2+}$. Removal of $\mathrm{Cd}^{2+}$ and $\mathrm{Pb}^{2+}$ from actual groundwater using KPP and MKPP was also demonstrated.

Fixed-bed $\mathrm{Pb}^{2+}$ removal using KPP exhibited a column capacity of $18.8 \mathrm{mg} \mathrm{g}^{-1}$. Regeneration of spent KPP in the column using $0.1 \mathrm{~N} \mathrm{HCl}$ gave an $85 \%$ recovery of total $\mathrm{Pb}^{2+}$ using the first ten aliquots of $\mathrm{HCl}$ and the remaining $\mathrm{Pb}^{2+}$ was recovered in further increments.

\section{Acknowledgements}

One of the authors, RS, thankfully acknowledges the financial support for this work provided by CSIR. Authors are also thankful to University Grant Commission (UGC), New Delhi for providing the financial assistance under $21^{\text {st }}$ Century Indo-US Research Initiative 2014 to Jawaharlal Nehru University, New Delhi and Mississippi State University, USA in the project "Clean Energy and Water Initiatives" [UGC No. F.194-1/ 2014(IC)]. One of the authors (DM) is also thankful to Jawaharlal Nehru University for providing financial assistance under Second phase of University with Potential of Excellence (UPOE II) grant (ID 189). Authors also acknowledge the funding support from DST PURSE, Government of India. The study is also supported by Indo-Sri Lankan joint research project grant (No. INT/SL/12/P-008) provided by Department of Science and Technology (DST), Government of India.

\section{References}

1 V. K. Singh, D. S. Bikundia, A. Sarswat and D. Mohan, Environ. Monit. Assess., 2012, 184, 4473-4488.

2 J. Fawell and M. J. Nieuwenhuijsen, Br. Med. Bull., 2003, 68, 199-208.

3 S. Chouhan and S. J. S. Flora, Indian J. Exp. Biol., 2010, 48, 666-678.

4 M. Kumari, C. U. Pittman Jr and D. Mohan, J. Colloid Interface Sci., 2015, 442, 120-132. 
5 D. Mohan, H. Kumar, A. Sarswat, M. Alexandre-Franco and C. U. Pittman Jr, Chem. Eng. J., 2014, 236, 513-528.

6 M. Tsezos, Hydrometallurgy, 2001, 59, 241-243.

7 Y.-S. Ho and A. E. Ofomaja, Biochem. Eng. J., 2006, 30, 117123.

8 D. Mohan, C. U. Pittman Jr, M. Bricka, F. Smith, B. Yancey, J. Mohammad, P. H. Steele, M. F. Alexandre-Franco, V. Gómez-Serrano and H. Gong, J. Colloid Interface Sci., 2007, 310, 57-73.

9 Environmental Inorganic Chemistry: Properties, Processes, and Estimation Methods, ed. W. J. Lyman, W. F. Reehl and D. H. Rosenblatt, Pergamon press, New York, 1988.

10 P. Grover, P. V. Rekhadevi, K. Danadevi, S. B. Vuyyuri, M. Mahboob and M. F. Rahman, Int. J. Hyg. Environ. Health, 2010, 213, 99-106.

11 E. M. Mager, K. V. Brix, K. R. M. Gerdes, A. C. Ryan and M. Grosell, Ecotoxicol. Environ. Saf., 2011, 74, 238-243.

12 L. Järup, Br. Med. Bull., 2003, 68, 167-182.

13 WHO, WHO Guidelines for Drinking-Water Quality, WHO Press, Geneva, 4th edn, 2011.

14 BIS, Bureau of Indian Standard, Indian standard specification for drinking water, BIS, Delhi, IS 10500, 1991, pp. 2-4.

15 BIS, Drinking Water Specification, Second Revision IS: 10500: 2012, Bureau of Indian Standards, New Delhi, India, 2012.

16 K. S. Low, C. K. Lee and S. C. Liew, Process Biochem., 2000, 36, 59-64.

17 K. Y. Foo and B. H. Hameed, J. Hazard. Mater., 2010, 175, 111.

18 S. K. R. Yadanaparthi, D. Graybill and R. v. Wandruszka, J. Hazard. Mater., 2009, 171, 1-15.

19 O. Yavuz, R. Guzel, F. Aydin, I. Tegin and R. Ziyadanogullari, Pol. J. Environ. Stud., 2007, 16, 467.

20 Y. Huang, C. Yang, Z. Sun, G. Zeng and H. He, RSC Adv., 2015, 5, 11475-11484.

$21 \mathrm{~J}$. Wang and C. Chen, Biotechnol. Adv., 2006, 24, 427-451.

22 J. Wang and C. Chen, Biotechnol. Adv., 2009, 27, 195-226.

23 A. Jusoh, L. S. Shiung, N. a. Ali and M. J. M. M. Noor, Desalination, 2007, 206, 9-16.

24 T. Robinson, G. McMullan, R. Marchant and P. Nigam, Bioresour. Technol., 2001, 77, 247-255.

25 E. Fourest, C. Canal and J. C. Roux, FEMS Microbiol. Rev., 1992, 14, 325-332.

26 K. Mohanty, M. Jha, B. C. Meikap and M. N. Biswas, Chem. Eng. J., 2006, 117, 71-77.

27 A. Moubarik and N. Grimi, Food Res. Int., 2015, 73, 169-175.

28 C. Pennesi, C. Totti, T. Romagnoli, B. Bianco and I. D. Michelis, Water Environ. Res., 2012, 84, 9-16.

29 S. Balaji, T. Kalaivani, C. Rajasekaran, M. Shalini, R. Siva, R. K. Singh and M. A. Akthar, Clean: Soil, Air, Water, 2014, 42, 1790-1797.

30 D. Sharmila and P. Muthusamy, J. Chem. Pharm. Res., 2013, 5, 10-13.

31 A. Jakóbik-Kolon, A. K. Milewski, K. Mitko and A. Lis, Sep. Sci. Technol., 2014, 49, 1679-1688.

32 Z. R. Holan and B. Volesky, Appl. Biochem. Biotechnol., 1995, 53, 133-146.
33 C. K. Jain, D. S. Malik and A. K. Yadav, Environ. Processes, 2016, 3, 495-523.

34 P. Krishen, Trees of Delhi: a field guide, Penguin Books, India, 2006.

35 T. K. Lim, Bauhinia purpurea, in Edible Medicinal And NonMedicinal Plants, Springer, Netherlands, 2014, pp. 743-753.

36 H. V. Annegowda, M. N. Mordi, S. Ramanathan, M. R. Hamdan and S. M. Mansor, Food Analytical Methods, 2012, 5, 226-233.

37 E. F. Fang, C. S. F. Bah, J. H. Wong, W. L. Pan, Y. S. Chan, X. J. Ye and T. B. Ng, Arch. Toxicol., 2012, 86, 293-304.

38 B. S. Negi, B. P. Dave and Y. K. Agarwal, Indian J. Microbiol., 2012, 52, 360-365.

39 N. Neelapu and S. Muvvala, Int. J. Res. Phytochem. Pharmacol., 2012, 1, 97-102.

40 A. Kanwal, S. A. Mirza and M. Farhan, Pak. J. Bot., 2015, 47, 275-280.

41 K. Polipalli and K. Pulipati, Int. J. Sci. Eng. Res., 2013, 4, 1244-1252.

42 E. P. Barrett, L. G. Joyner and P. P. Halenda, J. Am. Chem. Soc., 1951, 73, 373-380.

43 M. M. Dubinin, in Progress in Surface and Membrane Science, ed. D. A. Cadenhead, J. F. Danielli and M. D. Rosenberg, Academic Press, NewYork and London, 1975, pp. 1-70.

44 M. M. Dubinin and G. M. Plavnik, Carbon, 1968, 6, 183-192. 45 ASTM-D1762-84, ASTM International, Standard test method for chemical analysis of wood charcoal, ASTM International, Pennsylvania, 2007.

46 H. M. F. Freundlich, J. Phys. Chem., 1906, 57, 385-471.

47 I. Langmuir, J. Am. Chem. Soc., 1916, 38, 2221-2295.

48 M. I. Temkin and V. Pyzhev, Acta physicochimica U.R.S.S., 1940, 12, 217-222.

49 R. Sips, J. Chem. Phys., 1948, 16, 490-495.

50 O. Redlich and D. L. Peterson, J. Phys. Chem., 1959, 63, 1024.

51 C. J. Radke and J. M. Prausnitz, Ind. Eng. Chem. Fundam., 1972, 11, 445-451.

52 J. Toth, Acta Chim. Acad. Sci. Hung., 1971, 69, 311-317.

53 R. Koble and T. Corrigan, Ind. Eng. Chem. Fundam., 1952, 44, 383-387.

54 S. Lagergren, Handlingar, 1898, 24, 1-7.

55 Y. S. Ho and G. McKay, Process Biochem., 1999, 34, 451.

56 D. Mohan and S. Chander, J. Colloid Interface Sci., 2006, 299, 76-87.

57 N. F. Cardoso, E. C. Lima, I. S. Pinto, C. V. Amavisca, B. Royer, R. B. Pinto, W. S. Alencar and S. F. P. Pereira, J. Environ. Manage., 2011, 92, 1237-1247.

58 S. Nanda, P. Mohanty, K. K. Pant, S. Naik, J. A. Kozinski and A. K. Dalai, BioEnergy Res., 2013, 6, 663-677.

59 A. C. Correa, E. D. M. Teixeira, L. A. Pessan and L. H. C. Mattoso, Cellul. Chem. Technol., 2010, 17, 11831192.

60 S. V. Vassilev, D. Baxter, L. K. Andersen, C. G. Vassileva and T. J. Morgan, Fuel, 2012, 94, 1-33.

61 K. Umamaheswaran and V. S. Batra, Fuel, 2008, 87, 628638.

62 T. Madrakian, A. Afkhami, M. Ahmadi and H. Bagheri, J. Hazard. Mater., 2011, 196, 109-114. 
63 Q. Peng, Y. Liu, G. Zeng, W. Xu, C. Yang and J. Zhang, J. Hazard. Mater., 2010, 177, 676-682.

64 A. B. Albadarin, C. Mangwandi, G. M. Walker, S. J. Allen, M. N. M. Ahmada and M. Khraisheh, J. Environ. Manage., 2013, 114, 190-201.

65 J. R. Koduru, Y.-Y. Chang, J.-K. Yang and I.-S. Kim, Sci. World J., 2013, 2013, 1-14.

66 M. Namdeo and S. K. Bajpai, Electron. J. Environ., Agric. Food Chem., 2009, 8, 3082-3094.

67 K. Chitra and G. Annadurai, Biocybern. Biomed. Eng., 2014, 34, 230-237.

68 V. K. Singh and K. R. C. Reddy, Int. J. Res. Phytochem. Pharmacol., 2015, 3, 386-390.

69 S. S. Banerjee and D.-H. Chen, J. Hazard. Mater., 2007, 147, 792-799.

70 S. Yorgun and D. Yıldız, J. Anal. Appl. Pyrolysis, 2015, 114, 68-78.

71 M. Fereidouni, A. Daneshi and H. Younes, J. Hazard. Mater., 2009, 168, 1437-1448.

72 A. M. Petrosyan, Vib. Spectrosc., 2007, 43, 284-289.

73 H. Schulz and M. Baranska, Vib. Spectrosc., 2007, 43, 13-25.

74 S. H. Kim, C. M. Lee and K. Kafle, Korean J. Chem. Eng., 2013, 30, 2127-2141.

75 A. Ahmad, M. Rafatullah, O. Sulaiman, M. H. Ibrahim, Y. Y. Chii and B. M. Siddique, Desalination, 2009, 247, 636-646.

76 D. Asandei, L. Bulgariu and E. Bobu, Cellul. Chem. Technol., 2009, 43, 211-216.

77 K. Chojnacka, A. Chojnacki and H. Gorecka, Chemosphere, 2005, 59, 75-84.

78 Y. Ding, D. Jing, H. Gong, L. Zhou and X. Yang, Bioresour. Technol., 2012, 114, 20-25.

79 T. Kumar and K. S. Chandrashekar, Res. J. Med. Plants, 2011, 5, 420-431.

80 Z. Wang, G. Liu, H. Zheng, F. Li, H. H. Ngo, W. Guo, C. Liu, L. Chen and B. Xing, Bioresour. Technol., 2015, 177, 308317.

81 W.-J. Liu, F.-X. Zeng, H. Jiang and H.-Q. Yu, Cellul. Chem. Technol., 2011, 50, 5920-5926.

82 Y. Cheng, C. Yang, H. He, G. Zeng, K. Zhao and Z. Yan, J. Environ. Eng., 2016, 142, C4015001, DOI: 10.1061/(asce) ee.1943-7870.0000956.
83 C. Yang, J. Wang, M. Lei, G. Xie, G. Zeng and S. Luo, J. Environ. Sci., 2010, 22, 675-680.

84 T. A. Davis, B. Volesky and A. Mucci, Water Res., 2003, 37, 4311-4330.

85 K. R. Hall, L. C. Eagleton, R. Acrivos and T. Vermeulen, Ind. Eng. Chem. Fundam., 1966, 5, 212-223.

86 D. Mohan, A. Sarswat, V. K. Singh, M. Alexandre-Franco and C. U. Pittman Jr, Chem. Eng. J., 2011, 172, 1111-1125.

87 A. Sarswat and D. Mohan, RSC Adv., 2016, 6, 85390-85410.

88 W. J. Weber Jr, Physicochemical Processes for Water Quality Control, Wiley, 1972.

89 A. H. Hawari and C. N. Mulligan, Process Biochem., 2006, 41, 187-198.

90 J. Anwar, U. Shafique, Waheed-uz-Zaman, M. Salman, A. Dar and S. Anwar, Bioresour. Technol., 2010, 101, 17521755.

91 R. Ahmad and S. Haseeb, Groundwater for Sustainable Development, 2015, vol. 1, pp. 41-49.

92 S. Guo, L. Z. Wei Li, J. Peng, H. Xia and S. Zhang, Process Saf. Environ. Prot., 2009, 87, 343-351.

93 M. S. Al-Masri, Y. A. B. Al-Akel and T. Al-Naama, Appl. Biochem. Biotechnol., 2010, 160, 976-987.

94 E. S. Z. El-Ashtoukhy, N. K. Amin and O. Abdelwaha, Desalination, 2008, 223, 162-173.

95 M. Al-Saraj, M. S. Abdel-Latif, I. El-Nahal and R. Barak, J. Non-Cryst. Solids, 1999, 248, 37-40.

96 M. D. Meitei and P. N. V. Majeti, Ecol. Eng., 2014, 71, 308317.

97 J. Yu, M. Tong, X. Sun and B. Li, React. Funct. Polym., 2007, 67, 564-572.

98 M. Rajeswari, P. Agrawal, S. Pavithra, Priya, G. R. Sandhya and G. M. Pavithra, Biotechnol. Bioprocess Eng., 2013, 18, 321-325.

99 U. Kumar and M. Bandyopadhyay, Bioresour. Technol., 2006, 97, 104-109.

100 P. Pavasant, R. Apiratikul, V. Sungkhum, P. Suthiparinyanont, S. Wattanachira and T. F. Marhaba, Bioresour. Technol., 2006, 97, 2321-2329.

101 I. Ghodbane, L. Nouri, O. Hamdaoui and M. Chiha, J. Hazard. Mater., 2008, 152, 148-158. 